\title{
Levels and congener distributions of PCDDs, PCDFs and dioxin-like PCBs in environmental and human samples: a review
}

\author{
K. Srogi
}

Received: 20 January 2007/ Accepted: 3 March 2007/Published online: 19 July 2007

(C) Springer-Verlag 2007

\begin{abstract}
The term "dioxins" is often used in a confusing way. In toxicological considerations-and also in the present report- the term is used to designate the PCDDs, the PCDFs and the coplanar ("dioxin-like") PCBs, since these classes of compounds show the same type of toxicity. Because of the large number of congeners, relevant individual congeners are assigned with a toxic equivalency factor (TEF) that relate their toxicity to that of tetrachlorodibenzo- $p$-dioxin (TCDD) (2,3,7,8-TCDD) and are to be evaluated as dioxins. Each concentration of an individual congener in a mixture is multiplied with its TEF, and the resulting TCDD equivalents are added up and expressed as WHO-endorsed toxic equivalents (WHO-TEQ). Polychlorinated dibenzo-p-dioxins (PCDDs) and polychlorinated dibenzofurans (PCDFs) are mainly the by-products of industrial processes (such as metallurgical processing, bleaching of paper pulp, and the manufacturing of some herbicides and pesticides) but they can also result from natural processes like volcanic eruptions and forest fires. Waste incineration, particularly if combustion is incomplete, is among the largest contributors to the release of PCDDs and PCDFs into the environment. Due to their persistence, PCDDs, PCDFs and PCBs are part of the socalled persistent organic pollutants group of compounds that also include some chlorinated pesticides. Since they have a high lipophilicity and resist transformation, they bio-accumulate in animal and human adipose tissues. Consumption of food is considered as the major source of non-occupational human exposure to $\mathrm{PCDD} / \mathrm{Fs}$ with foodstuffs from animal origin accounting for more than
\end{abstract}

K. Srogi $(\square)$

Institute for Chemical Processing of Coal,

Zamkowa 1, 41-803 Zabrze, Poland

e-mail: krystynasrogi@ poczta.onet.pl
$90 \%$ of the human body burden. With meat, dairy, and fish products being the main contributors. The aim of the present review was to summarize experimental data regarding dioxin emissions from contaminated and uncontaminated biological and environmental samples, from the available literature. The information will be presented chronologically with respect to distribution in human milk, serum; food, water, air, soils and sediments.

Keywords Polychlorinated dibenzofurans .

Polychlorinated dibenzodioxins - Polychlorinated biphenyls · Human tissue - Soil · Water · Food · Air $\cdot$ Sediments $\cdot$ Occupational exposure

\section{Introduction}

The term "dioxin" refers to a class of structurally and chemically related halogenated aromatic hydrocarbons that includes polychlorinated dibenzodioxins (PCDDs or dioxins), polychlorinated dibenzofurans (PCDFs or furans) and the "dioxin-like" polychlorinated biphenyls (PCBs). Because of their chemistry, dioxins are both toxic and persistent in the environment. Dioxins and furans are included in the UNEP "Dirty Dozen", and Greenpeace describe dioxins as "some of the most dangerous chemicals on earth" (Davy 2004).

Dioxins are unwanted contaminants almost exclusively produced by industrial processes (Lustenhouwer et al. 1980; EPA 2004), including incineration of municipal solid waste (Hylander et al. 2003; Chang et al. 2001, 2004) or medicinal waste (Coutinho et al. 2006), chlorine bleaching of paper and pulp, and the manufacture of some pesticides, herbicides, and fungicides (Chen 2004). Dioxins did not exist prior to industrialization expect in very small amounts 
(Czuczwa et al. 1984); they can also result from natural processes like volcanic eruptions and forest fires (SCF 2001; JECFA 2002; Freeman and de Tejada 2002).

Polychlorinated biphenyls on the other hand have been produced commercially for some five decades starting from about 1920 , by direct chlorination of biphenyl. They were produced as mixtures; individual congeners were hardly synthesized. The various (commercial) technical PCBmixtures are characterized by their chlorine content, the brand names of which are known as 'Aroclor' (produced in the USA), 'Clophen' (produced in Germany), 'Phenoclor' (produced in France), 'Fenclor' (produced in Italy), and 'Kanechlor' (produced in Japan). These mixtures were used in a wide range of applications, such as coatings, inks, flame retardants and paints, but its major uses were in electronic appliances, heat-transfer systems, and hydraulic fluids. Due to the persistent nature of PCBs in the environment many countries decided in the 1970s to ban the use of PCBs in open applications. They may, however, still be in use in closed systems such as capacitors and transformers, but this use will decrease over time. Waste disposal, both of households and industrial waste, is the major source of PCB emissions into the environment (ATSDR 2000).

PCDDs and PCDFs are two series of organohalogenated substances, which form a group of 210 different substances and are divided into 135 PCDFs and 75 PCDDs. However, only the isomers presenting chlorine in the $2,3,7,8$ positions have been reported to be toxic to exposed organisms (Malisch 2000a; Fueno et al. 2002). This reduces the number of compounds of interest to 17, 7 PCDDs and 10 PCDFs. Nevertheless, not all 2,3,7,8 chlorinated PCDDs/ PCDFs present the same toxicity; the 2,3,7,8 tetrachlorodibenzo- $p$-dioxin (TCDD) being the most toxic, was catalogued by the World Health Organization (WHO) as carcinogenic for humans (Abad et al. 2000a).

Because of the large number of congeners, relevant individual congeners are assigned with a toxic equivalency factor (TEF) (Van den Berg et al. 1998). The International Agency for Research on Cancer (IARC) named 2,3,7,8tetrachlorodibenzo- $p$-dioxins $(2,3,7,8$-TCDD) as a human carcinogen. Each concentration of an individual congener in a mixture is multiplied with its TEF, and the resulting TCDD equivalents are added up and expressed as WHOendorsed toxic equivalents (WHO-TEQ) (De Vito and Birnbaum 1995).

At present date, public concern over the adverse health effects of exposure to these toxicants has been enhanced by a number of dioxin contamination incidents involving food and feed. The contamination of milk, butter and meat by the use of contaminated citrus pulp in feedstuffs (Malisch 2000a, b), the Belgium dioxin episode in May 1999 in which a storage tank for animal fat was contaminated with
PCBs and dioxins, the 'natural' presence of dioxin in kaolinic clays widely used as agent feed additives (Abad et al. 2000a, b; Malisch 2000a; Rappe and Anderson 2000) or the contamination of chlorine chloride premixtures (Llerena et al. 2001) are some remarkable examples.

The quantitative analysis of dioxin-like compounds should ideally include all chemicals showing the same biological activity and the dioxin-like activity. Two approaches are commonly used. On one hand, chemical methods have a scope restricted to specific target chemicals, as listed in official regulations. Each chemical is affected by a relative toxicity coefficient, the toxic equivalent factor or TEF. The toxic equivalent quantity (TEQ) is the sum of all quantities of toxics weighted by their TEF. On the other hand, biological methods such as chemical-activated luciferase gene expression (CALUX) (Wouwe et al. 2004) or ethoxy-resorufin- $O$-deethylase (EROD) monitor the global toxicity of a given sample (Schroijen et al. 2004; Schwirzer et al. 1998; Van Loco et al. 2004). Discrepancies arise from either the presence of unknowns or the existence of synergic and antagonist effects at the biological level, which modulates the TEF values. The TEF values are in addition largely species dependent (Brenez et al. 2004).

This review article will focus mainly on the human health risk by dietary dioxins and their sources, occurrence in various environmental and biological (human) samples.

\section{Dioxins}

\section{Chemical structures and properties}

Dioxins, as they are commonly called, are PCDDs and PCDFs are compounds with similar chemical properties. Each compound comprises two benzene rings interconnected by oxygen atoms. In the case of PCDDs, the benzene rings are joined by two oxygen bridges, and in the case of the PCDFs, the benzene rings are connected by a carbon bond and an oxygen bridge. The general formula of the PCDDs, PCDFs and PCBs is shown in Fig. 1.

All PCDDs and PCDFs are organic solids with high melting points and low vapour pressures. They are characterized by extremely low water solubilities, and have a tendency for being strongly adsorbed on surfaces of particulate matter. The water solubility of dioxin and furans decreases and the solubility in organic solvents and fats increase with increasing chlorine content.

Some of the key properties of the dioxins are presented in Table 1 and full physico-chemical properties have been reviewed (Mackay et al. 1992; US EPA-1613 1994). There are 75 PCDDs and 135 PCDFs, each differing in the number and position of the chlorine atoms. Each individual PCDD or PCDF is termed a congener (giving 210 in total), 


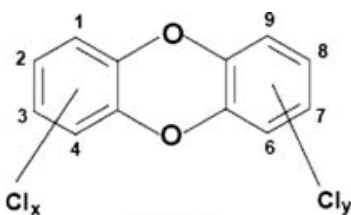

PCDD

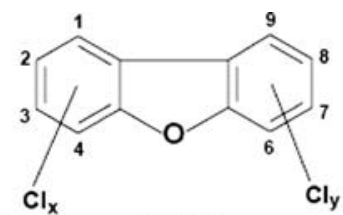

PCDF

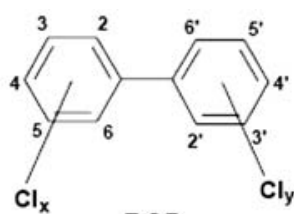

PCB
Fig. 1 General formula of polychlorinated dibenzo- $p$-dioxins $(P C D D s)$, polychlorinated dibenzofurans $(P C D F s)$ and polychlorinated biphenyls $(P C B s)$. The possible number of chlorine atoms results in 75 PCDD congeners and 135 PCDF congeners $(x=1-4$, $y=0-4)$, and 209 PCB congeners $(x=1-5, y=0-5)$ (Baars et al. 2004)
Table 1 Typical

physicochemical properties of PCDD/Fs (after Mackay et al. 1992; US EPA-1613 1994)

\begin{tabular}{lllll}
\hline Homologue group & $\begin{array}{l}\text { Vapour pressure } \\
\left(\mathrm{mmHg} \text { at } 25^{\circ} \mathrm{C}\right)\end{array}$ & $\log K_{\text {0w }}$ & $\begin{array}{l}\text { Solubility } \\
\left(\mathrm{mg} \mathrm{L}^{-1} \text { at } 25^{\circ} \mathrm{C}\right)\end{array}$ & $\begin{array}{l}\text { Henry's } \\
\text { constant }\end{array}$ \\
\hline TCDD & $8.1 \times 10^{-7}$ & 6.4 & $3.5 \times 10^{-4}$ & $1.35 \times 10^{-3}$ \\
PeCDD & $7.3 \times 10^{-10}$ & 6.6 & $1.2 \times 10^{-4}$ & $1.07 \times 10^{-4}$ \\
HxCDD & $5.9 \times 10^{-11}$ & 7.3 & $4.4 \times 10^{-6}$ & $1.83 \times 10^{-3}$ \\
HpCDD & $3.2 \times 10^{-11}$ & 8.0 & $2.4 \times 10^{-6}$ & $5.14 \times 10^{-4}$ \\
OCDD & $8.3 \times 10^{-13}$ & 8.2 & $7.4 \times 10^{-8}$ & $2.76 \times 10^{-4}$ \\
TCDF & $2.5 \times 10^{-8}$ & 6.2 & $4.2 \times 10^{-4}$ & $6.06 \times 10^{-4}$ \\
PeCDF & $2.7 \times 10^{-9}$ & 6.4 & $2.4 \times 10^{-4}$ & $2.04 \times 10^{-4}$ \\
HxCDF & $2.8 \times 10^{-10}$ & 7.0 & $1.3 \times 10^{-5}$ & $5.87 \times 10^{-4}$ \\
HpCDF & $9.9 \times 10^{-11}$ & 7.9 & $1.4 \times 10^{-6}$ & $5.76 \times 10^{-4}$ \\
OCDF & $3.8 \times 10^{-12}$ & 8.8 & $1.4 \times 10^{-6}$ & $4.04 \times 10^{-5}$ \\
\hline
\end{tabular}

while groups of congeners with the same number of chlorine atoms are called homologues. The number of congeners in each homologue group is shown in Table 2 (Van den Berg et al. 1998; US EPA-1613 1994). The homologue groups are often abbreviated for convenience; for example, tetrachloro CDDs and CDFs (PCDD/Fs with four substituted chlorine atoms) are abbreviated to TCDDs and TCDFs, respectively, while the fully chlorinated octachloro congeners (eight substituted chlorine atoms) are abbreviated to OCDD and OCDF, respectively (Srogi 2007a).

Toxic equivalent schemes

It is widely accepted that the toxicologically active PCDDs and PCDFs exert their effects by a common mechanism involving binding to a cytoplasmic receptor protein called the Ah (aryl hydrocarbon) receptor. Certain PCB congeners also bind to the $\mathrm{Ah}$ receptor and can exhibit similar toxicological effects to the 2,3,7,8-substituted PCDDs and PCDFs. Since these compounds are considered to act by a common mechanism, and because they occur as mixtures in the environment, in food, and in human tissues, they are commonly assessed and regulated as a class. However, detailed toxicological information is available only for TCDD. Therefore, the concept of "TCDD equivalents" or "toxic equivalents" has been introduced to enable the assessment of the toxicity of mixtures of these compounds
Table 2 Homologues and congeners of PCDDs and PCDFs (Van den Berg et al. 1998; US EPA-1613 1994)

\begin{tabular}{lll}
\hline Homologue (abbreviation) & \multicolumn{2}{l}{ Number of congeners } \\
\cline { 2 - 3 } & PCDDs & PCDFs \\
\hline Monochloro (M) & 2 & 4 \\
Dichloro (D) & 10 & 16 \\
Trichloro (Tr) & 14 & 28 \\
Tetrachloro (T) & 22 & 38 \\
Pentachloro (Pe) & 14 & 28 \\
Hexachloro (Hx) & 10 & 16 \\
Heptachloro (Hp) & 2 & 4 \\
Octachloro (O) & 1 & 1 \\
Nonachloro & & \\
Decachloro & & 135 \\
Total & 75 & \\
\hline
\end{tabular}

and to enable risk assessments of these mixtures to be carried out. This concept uses the available toxicological and in vitro biological data, and knowledge of structural similarities among the 2,3,7,8-substituted PCDD and PCDF congeners and the 13 "dioxin-like" $\mathrm{PCB}$ congeners (hereafter collectively termed "dioxins"), to generate a set of weighting factors or "toxic equivalency factors", each of which expresses the toxicity of a particular congener in terms of an equivalent amount of TCDD. Multiplication of 
the concentration of the congener by its TEF gives a TCDD toxic equivalent (TEQ) (Pollitt 1999).

The TEQ concept was first developed in New York by the State Health Department in a series of experiments in response to the need for reentry criteria of an office building contaminated by a mixture of dioxins following an electrical transformer fire (Eadon et al. 1986). The TEQ approach and current values have been adopted internationally as the most appropriate way to estimate the potential health risk of mixtures of dioxins. Table 3 lists these dioxins (Van den Berg et al. 1998).

The report of Liem (1999) revealed that dietary intake is the main route $(>90 \%)$ for human exposure to these toxicants. In view of this, in 1990, the World Health Organisation (WHO), based on the available data, suggested a tolerable daily intake (TDI) of $10 \mathrm{pg}$ I-TEQ bw to ensure that the human population would not be exposed to levels that could give rise to adverse effects (WHO 1991). However, in 1998 a new reevaluation recommended to further reduce the TDI between 1 and $4 \mathrm{pg}$ TEQ/ $\mathrm{kg}$ bw (Van Leeuwen et al. 2000a). Meanwhile, wide-ranging efforts and stringent regulations aimed at reducing the dioxin release have been in forced [(EC) No.194/97 1999].

\section{Human health risk by dietary dioxins}

The toxicology and human health effects of 2,3,7,8-tetrachlorodibenzo- $p$-dioxin (TCDD) and related compounds (i.e., the PCDDs and dibenzofurans, or PCDD/Fs) have been the focus of an extraordinary amount of research over the past 30 years (Srogi 2007b). Toxicologically, TCDD presents a range of interesting features, including its high degree of potency for several endpoints, its status as a confirmed animal carcinogen and teratogen, large inter-species and inter-strain variability in responses, and its receptor-based mechanism of toxicity (Hays and Aylward 2003; for e review, see ten Tusscher and Koppe 2004).

Body burdens of dioxins in breast-fed and non-breastfed individuals

Dioxins are extremely persistent and bioaccumulative (Schecter et al. 2006). The half-life of TCDD in rodents is usually 2-4 weeks but in humans it has been estimated to be of 7-11 years although with wide individual variation. Other dioxins may be eliminated more or less rapidly with as little as a 6-month half-life of elimination estimated for some PCDFs, but 20 years for others.

Thoma et al. (1990) have reported levels of dioxins (PCDD and PCDF congeners only) in adipose tissue from eight infants aged $2-13$ months and from 28 adults aged
Table 3 Toxic equivalency factors to express the toxicity of mixtures of PCDFs, PCDDs and PCBs in toxin equivalents of 2,3,7,8-TCDD (WHO-TEF) (Van den Berg et al. 1998)

\begin{tabular}{|c|c|}
\hline Structure & WHO-TEF \\
\hline \multicolumn{2}{|l|}{ PCDDs and PCDFs } \\
\hline $2,3,7,8-\mathrm{TCDD}$ & 1 \\
\hline 1,2,3,7,8-PeCDD & 1 \\
\hline $1,2,3,4,7,8-\mathrm{HxCDD}$ & 0.1 \\
\hline $1,2,3,6,7,8-\mathrm{HxCDD}$ & 0.1 \\
\hline 1,2,3,7,8,9-HxCDD & 0.1 \\
\hline 1,2,3,4,6,7,8-HpCDD & 0.01 \\
\hline OCDD & 0.0001 \\
\hline $2,3,7,8-\mathrm{TCDF}$ & 0.1 \\
\hline $1,2,3,7,8-\mathrm{PeCDF}$ & 0.05 \\
\hline 2,3,4,7,8-PeCDF & 0.5 \\
\hline $1,2,3,4,7,8-\mathrm{HxCDF}$ & 0.1 \\
\hline $1,2,3,6,7,8-\mathrm{HxCDF}$ & 0.1 \\
\hline $1,2,3,7,8,9-\mathrm{HxCDF}$ & 0.1 \\
\hline $2,3,4,6,7,8-\mathrm{HxCDF}$ & 0.1 \\
\hline $1,2,3,4,6,7,8-\mathrm{HpCDF}$ & 0.01 \\
\hline 1,2,3,4,7,8,9-HpCDF & 0.01 \\
\hline OCDF & 0.0001 \\
\hline \multicolumn{2}{|l|}{ Non-ortho PCBs } \\
\hline $3,3^{\prime}, 4,4^{\prime}-\mathrm{CB}(77)$ & 0.0001 \\
\hline $3,4,4^{\prime}, 5-\mathrm{CB}(81)$ & 0.0001 \\
\hline $3,3^{\prime}, 4,4^{\prime} 5-\mathrm{CB}(126)$ & 0.1 \\
\hline $3,3^{\prime}, 4,4^{\prime}, 5,5^{\prime}-\mathrm{CB}(169)$ & 0.01 \\
\hline \multicolumn{2}{|l|}{ Mono-ortho PCBs } \\
\hline $2,3,3^{\prime}, 4,4^{\prime}-\mathrm{CB}(105)$ & 0.0001 \\
\hline $2,3,4,4^{\prime}, 5-\mathrm{CB}(114)$ & 0.0005 \\
\hline $2,3^{\prime}, 4,4^{\prime}, 5-\mathrm{CB}(118)$ & 0.0001 \\
\hline $2,3,4,4^{\prime}, 5-\mathrm{CB}(123)$ & 0.0001 \\
\hline $2,3,3^{\prime}, 4,4^{\prime}, 5-\mathrm{CB}(156)$ & 0.0005 \\
\hline $2,3,3^{\prime}, 4,4^{\prime}, 5-\mathrm{CB}(157)$ & 0.0005 \\
\hline $2,3^{\prime}, 4,4^{\prime}, 5,5^{\prime}-\mathrm{CB}(167)$ & 0.00001 \\
\hline $2,3,3^{\prime}, 4,4^{\prime}, 5,5^{\prime}-\mathrm{CB}(189)$ & 0.0001 \\
\hline
\end{tabular}

31-80 years. The levels were lower in infants than in adults for all congeners except OCDF. Beck et al. (1990) measured the levels of dioxins (PCDD and PCDF congeners only) in the adipose tissue of a sudden infant-death baby (9.3 months old) who had been breast-fed for about 80 days. A level of $3.4 \mathrm{ng}$ TEQ/ $/ \mathrm{kg}$ body wt was found. In comparison, the levels in two non-breast-fed infants of 3.8 and 4.8 months of age were 2.8 and $2.1 \mathrm{ng} \mathrm{TEQ} / \mathrm{kg}$ body wt, respectively. This cannot be explained by low absorption of dioxins in the breast-fed infant, since the bioavailability of dioxins from human milk has been shown to be about 95\% (Pluim et al. 1993a). In another work 
(Laurent et al. 2002) reported a study of portal absorption of dioxin using three ${ }^{14} \mathrm{C}$-tagged compounds: ${ }^{14} \mathrm{Cphe}$ nanthrene, ${ }^{14} \mathrm{C}$-benzo[a]pyrene or ${ }^{14} \mathrm{CTCDD}$ (TCCD: 2,3,7,8-tetrachlorodibenzo- $p$-dioxin) in the growing pig. The analysis of portal and arterial blood radioactivity showed that TCDD was absorbed with a maximum concentration at 4-6 $\mathrm{h}$ after milk ingestion. Then, the blood radioactivity decreased to reach background levels $24 \mathrm{~h}$ after milk ingestion. Main ${ }^{14} \mathrm{C}$ absorption occurred during the 3-6 h time period for ${ }^{14} \mathrm{C}$-TCDD. These results indicate that TCDD was partly and weakly absorbed.

Pollitt (1999) proposed a number of conclusions:

1. If the assumption is made that the half-life of all dioxin congeners in human milk is identical to that of TCDD (9 years), breast feeding is predicted to result in a higher body burden of dioxins in early life, but not to result in an increased steady-state body burden, compared to that resulting from ingestion of the TDI of $10 \mathrm{pg} / \mathrm{kg}$ body wt/day from birth.

2. For congeners with a significantly lower half-life, e.g., 1-3 years, breast feeding will lead to higher body burdens in early life than would have been reached by ingestion of the TDI from birth. However, these peak body burdens will still be below the steady-state body burden achieved by ingestion of $10 \mathrm{pg}$ TCDD/kg body wt/day from birth.

3. The use of the toxic equivalent concept to estimate intakes of mixtures of dioxins is conservative when applied to congeners with half-lives shorter than that of TCDD, since it overestimates the likely accumulation of these congeners in human tissues.

4. The carcinogenicity study on which the TDI is based does not take account of any potential increased susceptibility to dioxins in early life. Otherwise, the TDI appears to accommodate the high intakes of dioxins by breast-fed babies, at least in relation to the end points on which it is based-carcinogenicity, fetotoxicity, and teratogenicity.

5. It is suggested that the toxicological database on TCDD is reexamined to assess whether postnatal development could be adversely affected by the high intakes of dioxins by infants during breast feeding.

6. More work is needed to assess whether breast-fed babies do achieve higher body burdens of dioxins than non-breast-fed babies, as predicted.

\section{Toxic effects of dioxin}

Dioxin-type chemicals produce a wide variety of speciesspecific effects including immunotoxicity, hepatotoxicity, birth defects, endocrine disruption, and the induction of numerous enzymes, most notably that of microsomal cyto- chrome P4501A1 (CYP1A1) and its associated mono-oxygenase activity, aryl hydrocarbon hydroxylase (for a review, see Diaz-Ferrero et al. 1997). Dioxins exert their effects via high-affinity binding to a specific cellular protein known as the arylhydrocarbon receptor (AhR) (Aoki 2001; Mitrou et al. 2001; Schecter and Gasiewicz 2003). The importance of this receptor is clearly evident from the observations that dioxin-induced symptoms, including organ atrophy and teratogenicity, are not present in AhR-knockout (KO) mice (Fernandez-Salguero et al. 1996). Thus, this receptor plays a crucial role in dioxin toxicity. However, immunosuppression produced by dioxins may occur by mechanism(s) not involving AhR. In connection with this, dioxin-induced changes in protein kinases (Brouwer et al. 1995; Denison and Heath-Pagliuso 1998), phospholipase $c$ (Beebe et al. 1990) and low-density lipoprotein receptors (Matsumura et al. 1984) have been suggested to occur via an AhRindependent mechanism. Thus, some forms of dioxin toxicity do not seem to require AhR (Ishida et al. 2005.).

In humans and other vertebrates dioxins have been shown to be the risk factors for cancer; immune deficiency; central and peripheral nervous system pathology; endocrine disruption, including diabetes and thyroid disorders; decreased pulmonary functions and bronchitis; altered serum testosterone level; eyelid pathology, including meibomian gland hypersecretion and hyperpigmented conjunctivae; gum pigmentation; nausea; vomiting; loss of appetite; skin rashes, including, rarely, chloracne or acne caused by chlorine-containing organic chemicals; hypertrichosis; liver damage; elevated serum cholesterol and triglycerides; and enamel hypomineralization of permanent first molars in children.

According to Kociba et al. (1976) chronic exposure to TCDD impairs reproduction. In males, TCDD and its congeners cause decreased spermatogenesis and testicular weight, as well as degeneration of the seminiferous tubules. In females, the morphological lesions observed in the uterus and ovaries during TCDD exposure suggest that the estrus cycle may be suppressed. In addition, under these conditions, plasma progesterone and estrogen concentration have been found to be decreased.

The reader interested by all problems associated with human effects from occupational and epidemiological studies of dioxins may find necessary details in the following works: WHO (1997), CDC (1998), IOM (2001, 2005), ten Tusscher and Koppe (2004).

\section{Exposure to dioxins}

Dioxins are persistent, toxic and bio-accumulative (PTB) chemicals and because they can be transported over long distances from the source of emission, they are also per- 
sistent organic pollutants (POPs). Combustion is considered a major source of the emissions of PCDDs and PCDFs. Dioxin production is a characteristic of controlled and uncontrolled combustion, e.g. wood (for a review, see Lavric et al. 2004) or pyrolysis process (Srogi 2007a) with strong relevance to health, safety and environmental issues in using biomass for energy (Lavric et al. 2004). Most important dioxin and furan air emission sources shown in Table 4 (Quaß et al. 2000).

Due to their physical properties, the bulk of the PCDD/F is adsorbed in dust and soot particles. These particles are deposited by atmospheric sedimentation (Masunaga et al. 2003) on soil and leafy vegetation such as grass. Depending on the distance from PCDD/F sources, deposition rates can vary considerably, and deposition rates exhibit strong seasonal trends.

In the following sections, main sources of $\mathrm{PCDD} / \mathrm{Fs}$ in ecosystem include human tissue, food, water, air, soils and sediments will be described.

\section{Human tissue}

Breast-milk monitoring programs have been implemented in various countries to assess the importance of human exposure to organohalogen compounds and to predict body burden in the breast-feeding infant. Several public health and environmental benefits result from monitoring breast milk for contaminants. First, breast milk samples offer a convenient and non-invasive means of monitoring humans for the presence of lipophilic compounds. Second, such contaminant data provide an insight into environmental conditions and historical human exposure. Third, these measures complement general environmental monitoring and provide a more accurate assessment of human exposures. Finally, the dose delivered to the nursing infant can be estimated (Hooper et al. 1997). The lipophilicity of dioxin and related chemicals promotes their sequestration in the adipose tissue of the breast and concentration in the milk during lactation (Jensen 1991). As a consequence, breast-fed infants can have daily exposures, 10-20 times higher than the background population (Jödicke et al. 1992; McLachlan 1993).

Yang et al. (2002) determined breast-milk concentration of PCDDs/PCDFs and PCBs in 24 mothers living in Korea, and assessed the maternal body burden based on PCDDs/ PCDFs and PCBs concentrations in breast milk and an infant intake rate through breast-feeding based on their concentration in breast milk. PCDDs/PCDFs and PCBs levels in breast milk from primipara mothers were found to be higher than those from multipara mothers. For total PCDDs/PCDFs TEQ level, 2,3,4,7,8-PeCDD was the predominant congener, and the proportion of 2,3,7,8-TCDD was less than $3 \%$ of total PCDDs/PCDFs TEQ level. For PCBs TEQ level, PCB-126 was the predominant congener. Maternal body burden levels of PCDDs/PCDFs and PCBs based on their concentrations in breast milk were 268622 TEQ ng. The daily dioxin intakes of mothers were predicted to be $0.78-2.18 \mathrm{TEQ} \mathrm{pg} / \mathrm{kg} /$ day for PCDDs/ PCDFs and 0.34-0.66 TEQ pg/kg/day for PCBs. For the first year, the body burden of an infant was predicted to be 212 TEQ ng and the daily intake of an infant was predicted to be 85 TEQ pg/kg/day, assuming the mean dioxin-related compounds concentration (27.54 TEQ pg/g fat).

Sasamoto et al. (2006) presented follow-up survey results of PCDDs, PCDFs, and dioxin-like PCBs' concentrations in human breast milk samples from 35 women living in Tokyo from whom samples had been obtained and analyzed to determine the corresponding concentrations in the past. The average concentrations of total PCDDs, PCDFs, dioxin-like PCBs were 8.5, 5.5, 11 TEQ $\mathrm{pg} / \mathrm{g}$ fat for the first samples

Table 4 Most important dioxin and furan air emission sources (Quaß et al. 2000)

\begin{tabular}{llll}
\hline Source type & $\begin{array}{l}\text { PCDD/PCDF } \\
\text { (g I-TEQ/year) }\end{array}$ & Emissions & $\begin{array}{c}\text { Uncertainty } \\
\text { of EF/AR }\end{array}$ \\
\hline MSW incineration & $1,437-174$ & Decreasing trend & Low/low \\
Sinter plants & & & Medium/low \\
Residential wood combustion & $94,010-115$ & Extent of contaminated wood used uncertain & Medium/high \\
Clinical waste incineration & 816 & Few plant data and statistics & High/high \\
Wood preservation & 381 & From PCP-treated goods & V.high/v.high \\
Fires & 380 & & Medium/low \\
Non-ferrous metals & 136 & Mainly leaded fuel; decreasing trend & Low/low \\
Road transport & 111 & & \\
Total & 5545 & & \\
\hline
\end{tabular}

$I-T E Q$ international toxic equivalent, $E F$ emission factor, $A R$ activity rate

a Illegal domestic burning of MSW

b Sinter plant for recycled materials 
and 5.4, 4.0, $6.6 \mathrm{TEQ} \mathrm{pg} / \mathrm{g}$ fat for the second samples, respectively. The degrees of reduction of total PCDDs and total dioxin-like PCBs were higher than that of total PCDFs because 1,2,3,7,8-PeCDD, 2,3,4,7,8-PeCDF and 3,30,4,40,5-PeCB (\#126), which were the predominant congeners among PCDDs, PCDFs, and dioxin-like PCBs, respectively, had different degrees of reduction. Moreover they observed a significant increase of the concentrations of PCDDs, PCDFs, and dioxin-like PCBs in samples from three women in this follow-up survey, and the patterns of increased isomers differed among the three samples. It was conjectured that the increase of the concentrations was due mainly to dietary intake between deliveries. It is important for pregnant women to have a balanced diet to mitigate the exposure of infants to these chemicals.

However, the total dioxin level in Japanese human milk was $250.4 \mathrm{pg} / \mathrm{g}$ fat on average (range $116.9-634.1 \mathrm{pg} / \mathrm{g}$ fat) for PCDDs + PCDFs + Co-PCBs, and their toxic equivalent was $22.0 \mathrm{pg} \mathrm{TEQ} / \mathrm{g}$ fat on average (range $7.3-49.7 \mathrm{pg}$ $\mathrm{TEQ} / \mathrm{g}$ fat). The OCDD level was the highest, accounting for 29.6\%. Next came PCB 126.24.3\%, then PCB169, $14.1 \%$. As for the contribution to TEF, 2,3,4,7,8-PeCDF accounted for $30.7 \%$, PCB126 accounted for $27.6 \%$ and 3,30,4,40,5-PeCDD accounted for 14.3\% (Takekuma et al. 2004). According to Hori et al. (1999) the level of total dioxin in human milk in 1973 (Japan) was $1920 \mathrm{pg} / \mathrm{g}$ fat (57.1 pg TEQ/g fat) for PCDDs + PCDFs + Co-PCBs, while the level of total dioxin in human milk (1996) was $279.9 \mathrm{pg} / \mathrm{g}$ fat $(24.1 \mathrm{pg}$ TEQ/g fat $)$ for PCDDs + PCDFs + Co-PCBs. Thus, dioxin levels showed a decreasing tendency from 1973, and it has been reported that the level decreased $85 \%$ (toxic equivalent: $58 \%$ ) during the period of 1973-1996.
According to Paumgartten et al. (2000) levels of PCDD/ Fs and PCBs in a pooled sample of breast milk from 40 mothers living in the city of Rio de Janeiro were low compared to concentrations generally found in more industrialized countries (Table 5). They concluded that PCDDs were found at higher concentrations than PCDFs and that, in both cases, concentrations progressively increased from tetra- to octachlorinated congeners except for OCDF. The overall concentration of PCDD/Fs in human milk sample, as expressed by 2,3,7,8-TCDD toxicity equivalents (I-TEQ) calculated according to NATO publications (NATO 1988a, b), was $8.1 \mathrm{pg}$ I-TEq/g milk fat, and 9.7 WHO-TEQ/g milk fat as computed according to WHO reevaluation (van den Berg et al. 1998), respectively. Although total PCDD/Fs and I-TEQ were low in mothers' milk from Rio de Janeiro, the concentrations of the highest chlorinated dioxin congeners, such as HpCDD and OCDD, in this sample tended to be slightly higher than levels generally found in more industrialized countries (WHO 1989, 1996). Recently, concentrations of PCDD/Fs and PCBs were determined in compost from 21 Brazilian municipal solid waste composing plants (Grossi et al. 1998). This study showed that concentrations of PCDD/Fs in Brazilian compost were similar to those found in Germany (Grossi et al. 1998). It was reported that PCBs were below the detection limit of the method in 29 individual samples of breast milk collected in Porto Alegre/Brazil in 1987/ 1988 (Beretta and Dick 1994). For this sample the PCB congener pattern is similar to that reported from other human milk samples of different origin (WHO 1996). Therefore the total PCB concentration can be estimated to be $0.15 \mathrm{mg} / \mathrm{g}$ milk fat by multiplying the sum of the concentrations from PCB-138, PCB-153, and PCB-180
Table $5 \mathrm{PCDD} / \mathrm{F}$

concentrations (pg I-TEQ/g fat) in human milk from different countries (after Paumgartten et al., 2000)

\begin{tabular}{lll}
\hline Sample/country & $\begin{array}{l}\text { I-TEQ } \\
\text { (pg/g milk fat) }\end{array}$ & Reference \\
\hline Paris/France, 1990 & 20.1 & González et al. (1996) \\
Madrid/Spain, 1990 & 13.3 & González et al. (1996) \\
Tarragona/Spain & 11.8 & Schuhmacher et al. (1999) \\
Kanado/Czech Republic, 1993 & 12.1 & Bencko et al. (1998) \\
Uhreské Hradistie/Czech Republic, 1993 & 18.4 & Bencko et al. (1998) \\
Canada, 1986-1987 & 15.0 & Ryan et al. (1993) \\
Germany, 1995 & 16.0 & Päpke (1998) \\
Germany, 1990 & 31 & Alder et al. (1994) \\
General population/China & 2.6 & Schecter et al. (1994) \\
Exposed to pentachlorophenol/China & 5.4 & Schecter et al. (1994) \\
Hanoi/Vietnam, 1988 & 2.1 & Schecter et al. (1998) \\
Southern Vietnam, 1985-1994 & $5.2-11.0$ & Schecter et al. (1998) \\
Several locations, Kazakhstan, 1994 & $7.0-57.2$ & Hooper et al. (1998) \\
Rio de Janeiro/Brazil & 8.1 & Paumgartten et al. (2000) \\
\hline
\end{tabular}


(Ballschmiter and Zell 1980) with a factor of 1.6 (Schulte and Malisch 1984).

It should be noted that, a correlation between dioxin content in mothers' milk and thyroid function in the mothers as well as their infants was also reported by Koopman-Esseboom et al. (1994) in The Netherlands, i.e., higher dioxin levels in human milk correlated with lower levels of maternal thyroid hormones, and with higher plasma levels of TSH in the infants in the second week and third month after birth. Nagayama et al. (1997) reported a significant positive correlation between serum TSH and a negative correlation between T4 and estimated total intakes of dioxins and PCB from the breast milk. The levels of serum TSH and T4 were within normal ranges in their report. However, Matsuura et al. (2001a, b) could not find any correlation between serum levels of TSH, FT4 and estimated intake of dioxins. These authors collected breast milk at the second week after delivery and examined serum thyroid functions at 9-14 days of age (Koopman-Esseboom et al. 1994). Dioxin content in breast milk was higher in the early days after delivery than that of later days.

The mean level of the total dioxin in the milk of 95 mothers who smoked was $227.3 \mathrm{pg} / \mathrm{g}$ fat (19.8 pg TEQ/g fat), while the mean level of 204 mothers who did not smoke was $261.2 \mathrm{pg} / \mathrm{g}$ fat (23.1 pg TEQ/g fat). Most congener levels of the mothers who smoked were lower than the mothers who did not smoke, and the covariance analysis showed that significant differences were found with most congeners (Takekuma et al. 2004). The amount of smoking showed the dioxin levels decreasing with increasing tobacco consumption, supporting Fürst et al. (1992), who reported that mothers who are active, or even passive, smokers contain, on average significantly, lower $\mathrm{PCDD} / \mathrm{F}$ levels than non-smoking women. While one report (Pluim et al. 1993b) found that smoking habits were not related to dioxin levels, results here showed that the dioxin levels in milk of mothers who smoked were lower than for mothers who did not smoke, and the dioxin levels were generally lower for mothers who were heavy smokers. It is thought that smoking somehow influences the accumulation of dioxin in the body.

It seems clear that it is necessary to consider age, smoking history, lactation in infancy and dietary habits, when dioxin levels are compared among individuals. It is particularly clear that the influence of smoking is significant. Life-style factors, such as smoking, age, and environmental factors, such as area of residence influenced the dioxin levels in human milk (Uehara et al. 2006).

In another work Chen et al. (2004) proposed the evaluation of the serum PCDD/F concentration distribution in residents in the vicinity of a MWI (municipal waste incinerators, Taiwan) and its association with the ambient predicted dioxin exposure. The highest PCDD/F congener level was OCDD, followed by $1,2,3,4,6,7,8-\mathrm{HpCDD}$, and OCDF; however, 1,2,3,6,7,8-HxCDD was the major contributors to TEQ. Results showed no significant correlations between serum and ambient PCDD/F levels. Residents exposed to the incinerator PCDD/F contamination did not seem to present higher PCDD/F serum concentrations. This might be explained by the fact that ambient exposure was not the single most important contributor to serum concentrations when compared to other sources of exposure such as dietary intake. This study also identified that higher serum concentrations of PCDD/Fs were presented in female groups, and older groups. The variation in serum PCDD/F levels was associated with gender and age, especially for 1,2,3,6,7,8-HxCDD, and OCDD, the two most major congeners contributing to the total PCDD/F levels. Similar patterns were also observed in other studies, especially a German study indicating increased body burden at older ages (Beck et al. 1994; Päpke 1998; Wittsiepe et al. 2000). Deml et al. (1996) also reported that all the congeners of hexa-, hepta- and octaCDD were higher in women than in men. The above variation might be explained by another study indicating that the increasing half-life of most PCDD/F congeners may be associated with age and gender (Flesch-Janys et al. 1996). In addition, Michalek et al. (1992) also reported that the half-life of 2,3,7,8-TCDD was found with a marginally significant change in the percentage of body fat in 36 members of Operation Ranch Hand-the Air Force unit responsible for the aerial spraying of Agent Orange in Vietnam. Therefore, it may be concluded that old age was likely to show increased accumulation of adipose tissue and decreased metabolism, while the effect was expected to vary with gender (Flesch-Janys et al. 1996).

Dahlgren et al. (2003) reported the results of environmental sampling and modeling in a neighborhood adjacent to a wood processing plant. This plant used creosote and pentachlorophenol (PCP) to treat wood for over 70 years. Between 1999 and 2001, environmental samples were obtained to quantify the level of environmental contamination from the wood-processing plant. Blood from ten residents was measured for chlorinated dioxins and dibenzofurans. Soil sediment samples from drainage ditches and attic/dust samples from nearby residents' homes were tested for PCDD/Fs. The dioxin congeners analysis of the ten residents revealed elevated valued for octachlorodibenzo- $p$ dioxin and heptachlorodibenzo- $p$-dioxin compatible with PCP as the source. The levels of carcinogenic PAHs were higher than background levels and were similar to soil contamination on wood-preserving sites. Wipe sampling in the kitchens of 11 homes revealed that 20 of the 33 samples were positive for octachlorinated dioxins with a mean value of $10.27 \mathrm{ng} / \mathrm{m}^{2}$. The soil, ditch samples, and positive wipe samples from the homes indicate a possible ongoing 
route of exposure to the contaminants in the homes of these residents. Modeled air exposure estimated for the woodprocessing waste chemicals indicate some air exposure to combustion products. The estimated air levels for tetrachlorodibenzodiozin in this neighborhood exceeded the recommended levels for these compounds in some states. The quantitative data presented suggest a significant contamination of a neighborhood by wood-processing waste chemicals. These findings suggest the need for more stringent regulations on waste discharges from wood treatment plants.

\section{Food}

Food is the main source of polychlorinated dibenzo- $p$-dioxin (PCDD), dibenzofuran (PCDF) and coplanar polychlorinated biphenyl (c-PCB) exposure for human, accounting for $98 \%$ of the total intake (for a review, see Fries 1995). It is also known that animal products like meat (Vartiainen and Hallkainen 1994), fish, milk and milk products (Schmid et al. 2003) or bovine adipose tissue and hen's eggs are the main contributors to human dioxin exposure in adults (Vartiainen and Hallkainen 1994; Parzefall 2002; Kim et al. 2004) and contribute largely to the human burden, as PCDD/Fs are bioaccumulated because of their lipophilicity and their low biodegradability (De Fré and Wevers 1998; Liem 1999; Focant et al. 2002; Ryan et al. 1987; Fernandes et al. 2004). Irigaray et al. (2005) on the base of results suggested the risk of a strong increase of $2,3,7,8$-TCDD in blood induced by lipolysis for animals or humans previously exposed to this dioxin.

Therefore, dioxin levels in milk can be used as indicators for the actual average local dioxin exposure by atmospheric deposition. In the past, cow's milk has been used for the evaluation of point source emissions (Travis and Hattermer-Frey 1991; Fries et al. 2002).

In a risk assessment of dioxins and dioxin-like PCBs in the diet, the Scientific Committee for Food (SCF) of the European Commission assessed a tolerable weekly intake (TWI) of $14 \mathrm{pg} / \mathrm{kg}$ body weight (bw) for these chemicals as toxic equivalents (WHO-TEQ), according to the WHO TEF scheme (European Commission 2001; Van den Berg et al. 1998). Exposure estimates, made by SCF, indicated that a proportion of the European population has a dietary intake of dioxins and dioxin-like PCBs, which is in excess of the TWI.

In accordance with the recommendations of the French Conseil supérieur d'hygiéne publique (1997) (and European Union recommendations), the results of analyses were interpreted according to a non-commercialization threshold of $5 \mathrm{pg}$ TEQ/g of fat (the "target" threshold being of $1 \mathrm{pg}$ TEQ/g of fat). For example, Durand et al. (2000) no concentration were found above the threshold recommended by the French Conseil supérieur d'hygiéne publique (1997) and by the European Union: $5 \mathrm{pg} \mathrm{TEQ} / \mathrm{g}$ of fat (the maximal observed concentration was $1.75 \mathrm{pg} \mathrm{TEQ} / \mathrm{g}$ of fat). Thus, the study showed a very low contamination level of the long-life half-skimmed drinking milk far below the target value of $1 \mathrm{pg} \mathrm{TEQ} / \mathrm{g}$ of fat. The observed results were of the same order of magnitude as results published in the literature for other countries (for example Germany (Blüthgen et al. 1996; Hipplein et al. 1996), UK [MAFF Food Surveillance Information Sheets, various years 100 (January 1997), 107 (June 1997), 120 and 123 (August 1997), 133 and 134 (November 1997), 136 (December 1997), 143 (March 1998)], Finland [Hallikainen and Vartiainen 1998), or Netherlands (Hendriks et al. 1996)].

Although consumption of poultry products contributes $5-10 \%$ of the estimated daily intake in industrial countries (Focant et al. 2002), the available literature on transfer of these pollutants from feed to chickens and eggs is limited. However, poultry products have already been highlighted several times in terms of food chain safety, notably in the US in 1997 (Hayward et al. 1999), when ball clay naturally contaminated with high levels of dioxins was added to poultry and fish feed. More recently, in Belgium, contaminated recycled mineral oil was introduced into animal feed, causing a vast economic and political crisis (Bernard et al. 2002). In both accidents, thousands of chickens and eggs were removed from the market in order to reduce exposure risk, resulting in significant economic losses. These events revealed a need to better understand transfer mechanisms of these pollutants from the animal environment to their various compartments, such as eggs, fat or meat. Although incidents of food-chain contamination have occurred many times through consumption of contaminated feedstuffs in commercial chicken farms, few studies have examined the transfer of dioxins and related compounds from commercial feed to chickens. Recently, Maervoet et al. (2004) have studied accumulation and tissue distribution of seven PCBs in chickens. Iben et al. (2003) fed broiler chickens with reasonably low dioxin level feed to determine contamination in edible tissue, and Hoogenboom et al. (2004) have investigated PCB and $\mathrm{PCDD} / \mathrm{F}$ kinetics in broiler after being fed contaminated feed.

For example, concentrations of PCDDs, PCDFs and CoPCBs in domestic animal-related samples were summarized in Table 6 (Guruge et al. 2005). Fish oil contained the highest concentration of PCDDs among feed ingredients. Concentrations of PCDDs were three- to tenfold greater than PCDFs in all the feed ingredients. Total PCDDs/ PCDFs concentration in fish oil was twofold greater than those in fishmeal and meat and bone meal. The detection frequencies were $100 \%$ for $1,2,3,4,6,7,8-\mathrm{HpCDD}$, OCDD and $1,2,3,4,6,7,8-\mathrm{HpCDF}$ in feed ingredients. These three 
Table 6 Mean and range of concentrations (pg g/1 lipid wt) of PCDDs, PCDFs and Co-PCBs in domestic animal related samples (Guruge et al. 2005)

\begin{tabular}{|c|c|c|c|c|c|c|c|c|}
\hline & Fish oil & Fish meal & $\begin{array}{l}\text { Meat and } \\
\text { bone meal }\end{array}$ & $\begin{array}{l}\text { Cattle } \\
\text { feed }\end{array}$ & $\begin{array}{l}\text { Chicken } \\
\text { feed }\end{array}$ & $\begin{array}{l}\text { Pig } \\
\text { feed }\end{array}$ & $\begin{array}{l}\text { Chicken } \\
\text { fat }\end{array}$ & $\begin{array}{l}\text { Pig } \\
\text { fat }\end{array}$ \\
\hline Number of samples & 5 & 7 & 5 & 1 & 2 & 2 & 5 & 3 \\
\hline Lipid (\%) & 100 & 9.5 & 11 & 4.8 & 5.1 & 3.6 & 77 & 78 \\
\hline 2,3,7,8-TeCDD & $\begin{array}{l}0.6 \\
(<0.02-1.2)\end{array}$ & $\begin{array}{l}0.05 \\
(<0.02-0.36)\end{array}$ & $\begin{array}{l}0.034 \\
(<0.02-0.17)\end{array}$ & $<0.02$ & $\begin{array}{l}<0.02 \\
<0.02\end{array}$ & $\begin{array}{l}<0.02 \\
<0.02\end{array}$ & $\begin{array}{l}<0.02 \\
<0.02\end{array}$ & $\begin{array}{l}<0.02 \\
<0.02\end{array}$ \\
\hline 1,2,3,7,8-PeCDD & $\begin{array}{l}0.9 \\
(0.66-1.1)\end{array}$ & $\begin{array}{l}0.13 \\
(<0.02-0.70)\end{array}$ & $\begin{array}{l}<0.02 \\
<0.02\end{array}$ & $<0.02$ & $\begin{array}{l}<0.02 \\
<0.02\end{array}$ & $\begin{array}{l}<0.02 \\
<0.02\end{array}$ & $\begin{array}{l}0.23 \\
(<0.02-0.92)\end{array}$ & $\begin{array}{l}0.3 \\
(<0.02-0.87)\end{array}$ \\
\hline 1,2,3,4,7,8-HxCDD & $\begin{array}{l}0.63 \\
(<0.02-1.2)\end{array}$ & $\begin{array}{l}0.10 \\
(<0.02-0.39)\end{array}$ & $\begin{array}{l}0.077 \\
(<0.02-0.23)\end{array}$ & 0.26 & $\begin{array}{l}<0.02 \\
<0.02\end{array}$ & $\begin{array}{l}<0.02 \\
<0.02\end{array}$ & $\begin{array}{l}<0.02 \\
<0.02\end{array}$ & $\begin{array}{l}<0.02 \\
<0.02\end{array}$ \\
\hline 1,2,3,6,7,8-HxCDD & $\begin{array}{l}0.89 \\
(<0.02-1.4)\end{array}$ & $\begin{array}{l}0.12 \\
(<0.02-0.53)\end{array}$ & $\begin{array}{l}0.11 \\
(<0.02-0.52)\end{array}$ & 0.19 & $\begin{array}{l}<0.02 \\
<0.02\end{array}$ & $\begin{array}{l}<0.02 \\
<0.02\end{array}$ & $\begin{array}{l}0.43 \\
(<0.02-1.7)\end{array}$ & $\begin{array}{l}0.22 \\
(<0.02-0.65)\end{array}$ \\
\hline 1,2,3,7,8,9-HxCDD & $\begin{array}{l}<0.02 \\
<0.02\end{array}$ & $\begin{array}{l}0.09 \\
(<0.02-0.43)\end{array}$ & $\begin{array}{l}0.13 \\
(<0.02-0.40)\end{array}$ & 0.29 & $\begin{array}{l}<0.02 \\
<0.02\end{array}$ & $\begin{array}{l}0.22 \\
(<0.02-0.44)\end{array}$ & $\begin{array}{l}<0.02 \\
<0.02\end{array}$ & $\begin{array}{l}<0.02 \\
<0.02\end{array}$ \\
\hline 1,2,3,4,6,7,8-HpCDD & $\begin{array}{l}5.2 \\
(3.6-7.8)\end{array}$ & $\begin{array}{l}2.5 \\
(0.62-5.5)\end{array}$ & $\begin{array}{l}2.4 \\
(0.70-5.5)\end{array}$ & 2.5 & $\begin{array}{l}1.9 \\
(1.4-2.3)\end{array}$ & $\begin{array}{l}3 \\
(2.6-3.3)\end{array}$ & $\begin{array}{l}3.9 \\
(1.5-9.1)\end{array}$ & $\begin{array}{l}<0.02 \\
<0.02\end{array}$ \\
\hline OCDD & $\begin{array}{l}39 \\
(31-55)\end{array}$ & $\begin{array}{l}19 \\
(2.9-45)\end{array}$ & $\begin{array}{l}19 \\
(3.8-59)\end{array}$ & 9.5 & $\begin{array}{l}9.5 \\
(6.0-1.3)\end{array}$ & $\begin{array}{l}15 \\
(9.1-21)\end{array}$ & $\begin{array}{l}5.4 \\
(<0.02-14)\end{array}$ & $\begin{array}{l}11 \\
(7.4-14)\end{array}$ \\
\hline $2,3,7,8-\mathrm{TeCDF}$ & $\begin{array}{l}2.9 \\
(1.6-3.6)\end{array}$ & $\begin{array}{l}0.51 \\
(0.12-0.94)\end{array}$ & $\begin{array}{l}0.03 \\
(<0.02-0.13)\end{array}$ & $<0.02$ & $\begin{array}{l}0.18 \\
(0.10-0.26)\end{array}$ & $\begin{array}{l}<0.02 \\
<0.02\end{array}$ & $\begin{array}{l}3.2 \\
(2.1-4.6)\end{array}$ & $\begin{array}{l}0.27 \\
(<0.02-0.81)\end{array}$ \\
\hline $1,2,3,7,8-\mathrm{PeCDF}$ & $\begin{array}{l}1.5 \\
(<0.02-2.4)\end{array}$ & $\begin{array}{l}0.07 \\
(<0.02-0.27)\end{array}$ & $\begin{array}{l}<0.02 \\
<0.02\end{array}$ & $<0.02$ & $\begin{array}{l}0.17 \\
(<0.02-0.34)\end{array}$ & $\begin{array}{l}<0.02 \\
<0.02\end{array}$ & $\begin{array}{l}<0.02 \\
<0.02\end{array}$ & $\begin{array}{l}<0.02 \\
<0.02\end{array}$ \\
\hline 2,3,4,7,8-PeCDF & $\begin{array}{l}2.0 \\
2.0\end{array}$ & $\begin{array}{l}0.35 \\
(<0.02-0.69)\end{array}$ & $\begin{array}{l}0.08 \\
(<0.02-0.22)\end{array}$ & $<0.02$ & $\begin{array}{l}0.07 \\
(<0.02-0.14)\end{array}$ & $\begin{array}{l}0.12 \\
(<0.02-0.24)\end{array}$ & $\begin{array}{l}1.6 \\
(<0.02-3.4)\end{array}$ & $\begin{array}{l}0.47 \\
(<0.02-0.75)\end{array}$ \\
\hline $1,2,3,4,7,8-\mathrm{HxCDF}$ & $\begin{array}{l}0.50 \\
(<0.02-0.89)\end{array}$ & $\begin{array}{l}0.11 \\
(<0.02-0.37)\end{array}$ & $\begin{array}{l}0.039 \\
(<0.02-0.19)\end{array}$ & 0.21 & $\begin{array}{l}0.05 \\
(<0.02-0.10)\end{array}$ & $\begin{array}{l}<0.02 \\
<0.02\end{array}$ & $\begin{array}{l}0.75 \\
(<0.02-1.7)\end{array}$ & $\begin{array}{l}0.3 \\
(<0.02-0.91)\end{array}$ \\
\hline $1,2,3,6,7,8-\mathrm{HxCDF}$ & $\begin{array}{l}0.52 \\
(<0.02-0.88)\end{array}$ & $\begin{array}{l}0.10 \\
(<0.02-0.39)\end{array}$ & $\begin{array}{l}0.1 \\
(<0.02-0.49)\end{array}$ & $<0.02$ & $\begin{array}{l}0.08 \\
(<0.02-0.16)\end{array}$ & $\begin{array}{l}<0.02 \\
<0.02\end{array}$ & $\begin{array}{l}0.53 \\
(<0.02-1.6)\end{array}$ & $\begin{array}{l}0.14 \\
(<0.02-0.43)\end{array}$ \\
\hline $1,2,3,7,8,9-\mathrm{HxCDF}$ & $\begin{array}{l}<0.02 \\
<0.02\end{array}$ & $\begin{array}{l}<0.02 \\
<0.02\end{array}$ & $\begin{array}{l}<0.02 \\
<0.02\end{array}$ & $<0.02$ & $\begin{array}{l}0.19 \\
(<0.02-0.38)\end{array}$ & $\begin{array}{l}<0.02 \\
<0.02\end{array}$ & $\begin{array}{l}<0.02 \\
<0.02\end{array}$ & $\begin{array}{l}<0.02 \\
<0.02\end{array}$ \\
\hline 2,3,4,6,7,8-HxCDF & $\begin{array}{l}0.78 \\
(<0.02-1.5)\end{array}$ & $\begin{array}{l}0.08 \\
(<0.02-0.38)\end{array}$ & $\begin{array}{l}0.24 \\
(<0.02-1.2)\end{array}$ & $<0.02$ & $\begin{array}{l}0.15 \\
(<0.02-0.29)\end{array}$ & $\begin{array}{l}<0.02 \\
<0.02\end{array}$ & $\begin{array}{l}0.61 \\
(<0.02-1.3)\end{array}$ & $\begin{array}{l}<0.02 \\
<0.02\end{array}$ \\
\hline $1,2,3,4,6,7,8-\mathrm{HpCDF}$ & $\begin{array}{l}3.7 \\
(2.7-5.1)\end{array}$ & $\begin{array}{l}0.94 \\
(0.58-1.4)\end{array}$ & $\begin{array}{l}1.2 \\
(0.59-2.5)\end{array}$ & 1.5 & $\begin{array}{l}0.93 \\
(0.59-1.3)\end{array}$ & $\begin{array}{l}1.7 \\
(0.96-2.5)\end{array}$ & $\begin{array}{l}2.3 \\
(0.55-6.8)\end{array}$ & $\begin{array}{l}0.22 \\
(<0.02-0.66)\end{array}$ \\
\hline $1,2,3,4,7,8,9-\mathrm{HpCDF}$ & $\begin{array}{l}<0.02 \\
<0.02\end{array}$ & $\begin{array}{l}<0.02 \\
<0.02\end{array}$ & $\begin{array}{l}0.26 \\
(<0.02-1.3)\end{array}$ & $<0.02$ & $\begin{array}{l}<0.02 \\
<0.02\end{array}$ & $\begin{array}{l}<0.02 \\
<0.02\end{array}$ & $\begin{array}{l}<0.02 \\
<0.02\end{array}$ & $\begin{array}{l}<0.02 \\
<0.02\end{array}$ \\
\hline OCDF & $\begin{array}{l}2.5 \\
(<0.02-4.2)\end{array}$ & $\begin{array}{l}0.18 \\
(0.02-0.86)\end{array}$ & $\begin{array}{l}1.35 \\
(<0.02-3.9)\end{array}$ & 1.3 & $\begin{array}{l}1.5 \\
(0.71-2.3)\end{array}$ & $\begin{array}{l}1.4 \\
(<0.02-2.9)\end{array}$ & $\begin{array}{l}<0.02 \\
<0.02\end{array}$ & $\begin{array}{l}<0.02 \\
<0.02\end{array}$ \\
\hline $3,4,4^{\prime}, 5-\mathrm{TeCB}(81)$ & $\begin{array}{l}9.4 \\
(5.9-12)\end{array}$ & $\begin{array}{l}1.3 \\
(0.25-3.0)\end{array}$ & $\begin{array}{l}0.38 \\
(0.10-0.60)\end{array}$ & 0.11 & $\begin{array}{l}0.17 \\
(0.15-0.18)\end{array}$ & $\begin{array}{l}0.33 \\
(0.20-0.46)\end{array}$ & $\begin{array}{l}3.4 \\
(1.7-6.0)\end{array}$ & $\begin{array}{l}0.16 \\
(<0.07-0.35)\end{array}$ \\
\hline $3,3^{\prime}, 4,4^{\prime}-\mathrm{TeCB}(77)$ & $\begin{array}{l}130 \\
(75-170)\end{array}$ & $\begin{array}{l}24 \\
(8.7-46)\end{array}$ & $\begin{array}{l}6.5 \\
(3.5-10)\end{array}$ & 1.4 & $\begin{array}{l}1.7 \\
(0.97-2.5)\end{array}$ & $\begin{array}{l}2.5 \\
(2.2-2.9)\end{array}$ & $\begin{array}{l}40 \\
(19-60)\end{array}$ & $\begin{array}{l}2.5 \\
(1.6-2.8)\end{array}$ \\
\hline $3,3^{\prime}, 4,4^{\prime} 5-\mathrm{PeCB}(126)$ & $\begin{array}{l}76 \\
(64-95)\end{array}$ & $\begin{array}{l}10 \\
(2.2-19)\end{array}$ & $\begin{array}{l}1.3 \\
(0.64-2.7)\end{array}$ & 0.08 & $\begin{array}{l}0.42 \\
(0.37-0.48)\end{array}$ & $\begin{array}{l}0.71 \\
(0.46-0.97)\end{array}$ & $\begin{array}{l}8.4 \\
(3.7-14)\end{array}$ & $\begin{array}{l}0.45 \\
(<0.07-0.70)\end{array}$ \\
\hline $3,3^{\prime}, 4,4^{\prime}, 5,5^{\prime}-\mathrm{HxCB}(169)$ & $\begin{array}{l}18 \\
(<0.07-31)\end{array}$ & $\begin{array}{l}3.7 \\
(0.26-19)\end{array}$ & $\begin{array}{l}0.39 \\
(0.04-0.66)\end{array}$ & $<0.07$ & $\begin{array}{l}0.01 \\
(0.07-0.13)\end{array}$ & $\begin{array}{l}0.15 \\
(0.15-0.16)\end{array}$ & $\begin{array}{l}0.97 \\
(0.89-1.9)\end{array}$ & $\begin{array}{l}0.5 \\
(<0.07-0.76)\end{array}$ \\
\hline $2,3,3^{\prime}, 4,4^{\prime}-\mathrm{PeCB}(105)$ & $\begin{array}{l}3000 \\
(1,800-4,000)\end{array}$ & $\begin{array}{l}360 \\
(33-750)\end{array}$ & $\begin{array}{l}91 \\
(5.3-400)\end{array}$ & 4.9 & $\begin{array}{l}34 \\
(5.1-63)\end{array}$ & $\begin{array}{l}17 \\
(14-20)\end{array}$ & $\begin{array}{l}380 \\
(140-740)\end{array}$ & $\begin{array}{l}17 \\
(<0.07-33)\end{array}$ \\
\hline
\end{tabular}


Table 6 continued

\begin{tabular}{|c|c|c|c|c|c|c|c|c|}
\hline & Fish oil & Fish meal & $\begin{array}{l}\text { Meat and } \\
\text { bone meal }\end{array}$ & $\begin{array}{l}\text { Cattle } \\
\text { feed }\end{array}$ & $\begin{array}{l}\text { Chicken } \\
\text { feed }\end{array}$ & $\begin{array}{l}\text { Pig } \\
\text { feed }\end{array}$ & $\begin{array}{l}\text { Chicken } \\
\text { fat }\end{array}$ & $\begin{array}{l}\text { Pig } \\
\text { fat }\end{array}$ \\
\hline $2,3,4,4^{\prime}, 5-\mathrm{PeCB}(114)$ & $\begin{array}{l}230 \\
(150-290)\end{array}$ & $\begin{array}{l}23 \\
(2.0-55)\end{array}$ & $\begin{array}{l}7.6 \\
(0.80-32)\end{array}$ & 0.97 & $\begin{array}{l}2.5 \\
(0.38-4.6)\end{array}$ & $\begin{array}{l}2.2 \\
(2.0-2.3)\end{array}$ & $\begin{array}{l}34 \\
(20-54)\end{array}$ & $\begin{array}{l}7.6 \\
(5.6-9.3)\end{array}$ \\
\hline $2,3^{\prime}, 4,4^{\prime}, 5-\mathrm{PeCB}(118)$ & $\begin{array}{l}9200 \\
(5,600-12,000)\end{array}$ & $\begin{array}{l}1000 \\
(86-2,200)\end{array}$ & $\begin{array}{l}340 \\
(16-1,500)\end{array}$ & 11 & $\begin{array}{l}110 \\
(16-190)\end{array}$ & $\begin{array}{l}51 \\
(37-65)\end{array}$ & $\begin{array}{l}1300 \\
(400-2,500)\end{array}$ & $\begin{array}{l}160 \\
(130-180)\end{array}$ \\
\hline $2,3,4,4^{\prime}, 5-\mathrm{PeCB}(123)$ & $\begin{array}{l}1500 \\
(320-2,400)\end{array}$ & $\begin{array}{l}110 \\
(7.8-460)\end{array}$ & $\begin{array}{l}10 \\
(1.2-39)\end{array}$ & 1.6 & $\begin{array}{l}11 \\
(0.78-21)\end{array}$ & $\begin{array}{l}4.9 \\
(3.3-4.0)\end{array}$ & $\begin{array}{l}75 \\
(47-130)\end{array}$ & $\begin{array}{l}6.5 \\
(4.1-10)\end{array}$ \\
\hline $2,3,3^{\prime}, 4,4^{\prime}, 5-\mathrm{HxCB}(156)$ & $\begin{array}{l}1100 \\
(690-1,500)\end{array}$ & $\begin{array}{l}140 \\
(10-280)\end{array}$ & $\begin{array}{l}27 \\
(1.8-110)\end{array}$ & 1.1 & $\begin{array}{l}6.6 \\
(1.9-11)\end{array}$ & $\begin{array}{l}6.3 \\
(3.9-8.6)\end{array}$ & $\begin{array}{l}76 \\
(30-140)\end{array}$ & $\begin{array}{l}43 \\
(41-47)\end{array}$ \\
\hline $2,3,3^{\prime}, 4,4^{\prime}, 5-\mathrm{HxCB}(157)$ & $\begin{array}{l}300 \\
(200-390)\end{array}$ & $\begin{array}{l}34 \\
(3.0-69)\end{array}$ & $\begin{array}{l}7.4 \\
(0.50-31)\end{array}$ & 0.22 & $\begin{array}{l}1.9 \\
(0.62-3.3)\end{array}$ & $\begin{array}{l}1.7 \\
(0.78-2.6)\end{array}$ & $\begin{array}{l}20 \\
(8.5-35)\end{array}$ & $\begin{array}{l}11 \\
(11-13)\end{array}$ \\
\hline $2,3^{\prime}, 4,4^{\prime}, 5,5^{\prime}-\mathrm{HxCB}(167)$ & $\begin{array}{l}930 \\
(640-1,300)\end{array}$ & $\begin{array}{l}170 \\
(21-380)\end{array}$ & $\begin{array}{l}47 \\
(1.1-210)\end{array}$ & 0.41 & $\begin{array}{l}4.8 \\
(3.0-6.7)\end{array}$ & $\begin{array}{l}8.7 \\
(2.0-15)\end{array}$ & $\begin{array}{l}170 \\
(20-350)\end{array}$ & $\begin{array}{l}58 \\
(28-82)\end{array}$ \\
\hline $2,3,3^{\prime}, 4,4^{\prime}, 5,5^{\prime}-\mathrm{HpCB}(189)$ & $\begin{array}{l}140 \\
(82-200)\end{array}$ & $\begin{array}{l}16 \\
(1.5-32)\end{array}$ & $\begin{array}{l}1.9 \\
(0.21-5.3)\end{array}$ & 0.25 & $\begin{array}{l}0.62 \\
(0.29-0.96)\end{array}$ & $\begin{array}{l}1.4 \\
(0.63-2.1)\end{array}$ & $\begin{array}{l}7.7 \\
(4.0-14)\end{array}$ & $\begin{array}{l}5.1 \\
(4.6-5.8)\end{array}$ \\
\hline
\end{tabular}

congeners were commonly found in various fish and farm animals (Fries 1995; Scortichini et al. 2001; Guruge and Tanabe 2004) suggesting that their contribution to animaloriginated feed ingredients were greater when compared to other PCDD/DF congeners. 2,3,7,8-TeCDF was found in all the fish oil and fishmeal samples while being found only in one imported meat and bone meal sample. The total concentrations of PCDDs and PCDFs in chicken feed (11 and $3.3 \mathrm{pg} / \mathrm{g}$ lipid wt) were similar to those in pig feed (18 and $3.2 \mathrm{pg} / \mathrm{g}$ lipid wt). Compared to PCDFs, four to sixfold higher PCDD concentrations were found in mixed feeds. Most of PCDDs congeners were not detected $(<0.02 \mathrm{pg} / \mathrm{g}$ lipid wt) in chicken feeds. Detection frequency was $100 \%$ for 1,2,3,4,6,7,8-HpCDD and OCDD, while most of other PCDDs and PCDFs were not detected in pig feed. This specific accumulation of PCDDs and PCDFs was identical to those earlier reported data for mixed animal feeds (McLachlan and Richter 1998; Scortichini et al. 2001).

The PCDF concentration in chicken fat $(9.0 \mathrm{pg}$ g lipid wt) was severalfolds higher than that of pig fat $(1.4 \mathrm{pg} / \mathrm{g}$ lipid wt), while PCDDs concentration was similar. Detection frequency was $100 \%$ for congeners $1,2,3,4,6,7,8$ HpCDD, OCDD and 1,2,3,4,6,7,8-HpCDF in chicken fat. Only congener OCDD was detected in all the pig fat samples. The chickens and pigs were approximately 6 months old when sampled. It was noticed that dioxin concentration in pig fat was decreased while unchanged in chicken fat during their later period of growth.

The sum of concentrations of 12 coplanar PCBs in fish oil was 17,000 pg/g lipid wt (Table 6) (Guruge et al. 2005). The fish oil accumulated 9- and 30-fold greater coplanar PCBs than those from fish meal and meat and bone meal, respectively. Fish oil is being strongly promoted as an aquaculture additive to improve the nutritional value to human in Europe (Jacobs et al. 2002). Therefore, these oils could contribute greatly to the contamination of farm-animals. Jacobs et al. (2002) noted that variation in oil sources and processing procedures could be result in inter batch differences in contamination levels in the final products. Guruge et al. (2005) also observed different concentrations of contaminants between imported and locally produced feed ingredients. Congener 118 accounted for the major proportion of the total coplanar PCB concentrations in all the samples. A similar bioaccumulation feature was observed in farmed fish food web (Jacobs et al. 2002) where congener 118 was predominated. Congener 77 was foremost throughout the domestic animal food web for nonortho PCBs.

Twelve chickens raised according to commercial standards were fed a diet containing about $30 \mathrm{ng} \mathrm{TEQ} / \mathrm{kg}$ for 10 weeks (Pirard and Pauw 2005). Persistent pollutants were introduced into the poultry feed via recycled oil to mimic contamination conditions closely resembling those occurring during the Belgian crisis 5 years ago. Absorption of congeners with the same chlorination degree did not seem to depend on the substitution, demonstrating that unlike for cows, no preferential absorption for 2,3,7,8substituted compounds could be observed for chickens. As already observed, absorption decreased with increasing number of chlorines and was not linearly dependent on the octanol/water partition coefficient. On the other hand, no real differences were observed in the absorption of c-PCBs with regard to degree of chlorination. When monitored during the course of experiment, concentrations of PCDD/ 
Fs and c-PCBs in excreta reached an apparent steady state after 5 weeks. Only 2,3,7,8-substituted dioxins or furans were found in tissues and eggs. All organs showed the same congener profile and similar lipid-normalized concentration, except for the liver. Bioconcentration factors were evaluated, highlighting that the liver preferentially retained highly chlorinated congeners. No depletion of dioxin and PCB concentration was observed after 8 and 14 weeks of control diet, but high inter-individual variation occurs.

According to Kim et al. (2001) concentrations of PCDDs in hamburgers (0-20 fg/g) were detected in lower levels than in fried chickens (16.92-252.00 fg/g). Specially fried chickens show the high contents of 2,3,7,8-TCDD and 1,2,3,7,8-PeCDD that have high TEQ factors (TEQ, 1.0). The TEQ levels of PCDDs in hamburger were lower than in fried chicken. Total TEQ level of PCDD in fried chicken was 47.45 times higher than in hamburger.

In USA, Scheter et al. (1995) reported values from 0.10 to $5.17 \mathrm{pg}$ I-TEQ/g, Fiedler et al. (1997a) presented mean values in chicken samples of $0.7 \pm 0.06$ with a maximum of 0.78 and a minimum of 0.61 , and Ferrario and Byrne (2000) mentioned values about $1.3 \mathrm{pg}$ I-TEQ/g. Fürst et al. (1990) reported poultry concentrations of 1.4 and $2.3 \mathrm{pg}$ I$\mathrm{TEQ} / \mathrm{g}$ in Germany. In Canada the concentration of PCDDs/PCDFs in poultry samples was $2.6 \mathrm{pg} \mathrm{I}-\mathrm{TEQ} / \mathrm{g}$ (Fürst et al. 1991) and Theelen et al. (1993) reported a concentration around $1.7 \mathrm{pg}$ I-TEQ/g in The Netherlands.

Kiviranta et al. (2004) have measured the concentrations of PCDD/F and PCBs in ten market baskets consisting of almost 4,000 individual food samples representing 228 different food items, and also in the total diet basket. Lower bound concentrations of PCDD/Fs ranged between 0.0057 and $5.6 \mathrm{pg} / \mathrm{g}$ fresh weight in the market baskets and the corresponding values for PCBs from 39 to $25.000 \mathrm{pg} / \mathrm{g}$. The fish basket contributed most to the concentrations of dioxins and PCBs, in which the lower bound range was from 0.82 to $850 \mathrm{pg} / \mathrm{g}$. These authors also assessed the average daily intakes of these substances by the Finnish adult population. The average daily intake of sum of PCDD/Fs and PCBs as WHO toxic equivalents was assessed to be $115 \mathrm{pg}$, which was $1.5 \mathrm{pg}$ WHO-TEQ/kg body weight using an average mean weight of $76 \mathrm{~kg}$ for the general population in Finland. The contribution of fish to the intake of PCDD/Fs was between 94 and $72 \%$, depending on whether lower or upper bound concentrations were used. With respect to PCBs, the contribution of fish was $80 \%$. Table 7 (Kiviranta et al. 2004) provides an overview of the average daily dietary intakes of dioxin- and PCB TEQs of adult populations from a number of countries. In addition, the food groups that contribute most to the intake of dioxins are resented. It is a difficult task to compare the results of intake estimations between countries because there are notable differences in the analytical methods, e.g., upper bound versus lower bound concentrations used and set of TEFs utilized. There are differences between studies in collection methods and number of foods analyzed, and differences in the means to study food consumption. The daily intake of dioxins ranged between 29 pg I-TEQ in Norway (SCOOP 2000) and 104 pg WHOPCDD/F-TEQ in the USA (Schecter et al. 2001a), and of PCBs from $31 \mathrm{pg}$ WHO-PCB-TEQ in Sweden (Lind et al. 2002) to 110 PCB-TEQ in Norway. The recent Finnish TEQ estimates of daily intakes (46-61 pg in dioxins and 51-60 in PCBs) were within these ranges reported from other countries. The Finnish daily intake of WHO-PCDD/ F-TEQ together with WHO-PCB-TEQ per bw was $1.5 \mathrm{pg} /$ $\mathrm{kg}$ bw in this study which is at the lower end of the tolerable daily-intake (TDI) range set by WHO, 1-4 pg TEQ/ $\mathrm{kg}$ bw (Van Leeuwen and Younes 2000b). None of the reported daily intakes in Table 7 (Kiviranta et al. 2004) exceeded the WHO TDI upper range value. The TWI of TEQs in Finland was $10.5 \mathrm{pg}$ WHO-TEQ/kg bw, which is also below the highest recommended TWI value of $14 \mathrm{pg}$ WHO-TEQ/kg bw given by EU (2001). In the future, analyses using distributional information for consumption data are needed in order to assess the percentage of Finns exceeding the TWI.

The levels in milk are strongly correlated with the fat content of the milk (Noren 1988) and influenced by the concentration of adipose tissue. Infants are exposed to PCDDs, PCDFs, and dioxin-like PCBs prenatally and via breast milk (Päpke 1998; Schecter 1998; Schecter et al. 1998; Wang et al. 2004). In the most industrialized countries, concentrations of PCDD/Fs and other organochlorine compounds have been regularly monitored in human milk and a rather large database on the general population contamination is currently available.

In many countries, breast-milk samples have been used as a suitable source of material for examining the level of human exposure to these compounds. Moreover, breast milk is the main conduit for discharging these compounds from the human body, and it is known that the levels of these compounds in human breast milk from mothers nursing their second child are lower than those from mothers breast-feeding their first child (Fürst et al. 1989; Kiviranta et al. 1998).

In the another work (Lai et al. 2004), 100 (from Hong Kong) and 48 (from Guangzhou) breast milk extracts were collected to determine the levels of dioxin-like compounds, of which $65 \%$ and 68 of the samples, respectively, were found to contain detectable dioxin-like activities using the H4IIE cell EROD screening assay. The mean EROD-TEQ values of the 65 samples from Hong Kong ranged from 58.1 to $96.5 \mathrm{pg} / \mathrm{g}$ of milk fat while the 32 samples from Guangzhou showed mean values of 98.8-202.1 pg/g of 


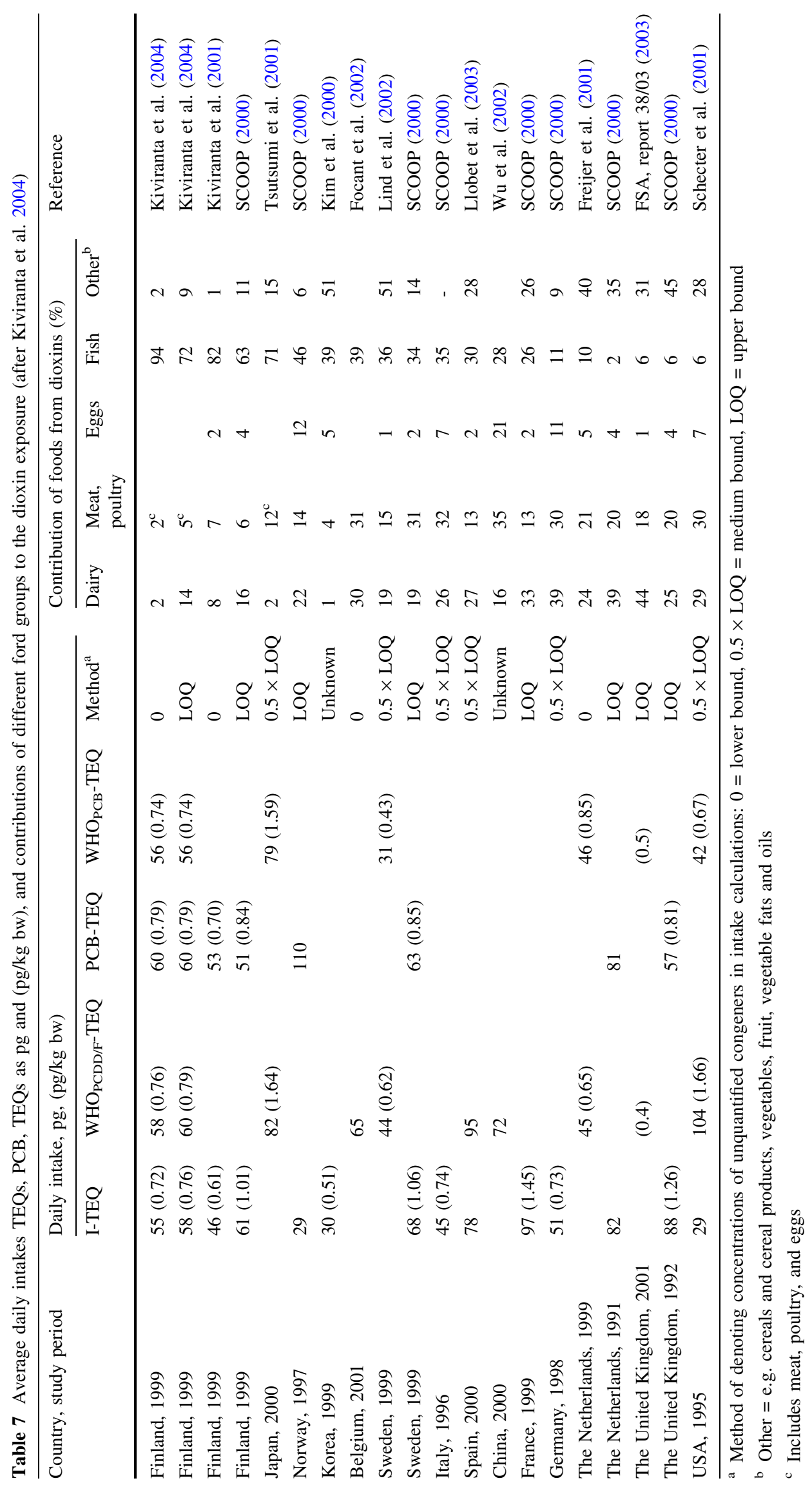


milk fat. The remaining samples (35\% of those from Hong Kong and $32 \%$ of those from Guangzhou) showed negative responses in the EROD screening assay. This might be attributable to the detection limit of the assay method, or dioxin-like compounds may truly have been absent in the samples. In comparing the EROD-TEQ values for the different age groups between the two cities, there were no significant differences $(P<0.05)$. However, the mean and median EROD-TEQ values for the Guangzhou population were in general higher than those for the Hong Kong group (Table 8). In other countries, the detectable dioxin concentrations, in terms of chemical-TEQ (C-TEQ), have been 9.6-35 pg/g fat (PCDD/PCDF) in Sweden (Glynn et al. 2001), 9.9-48.5 pg/g fat (PCDD/PCDF/CoPCB) in Japan (Nakagawa et al. 1999), 16-40.2 pg/g fat (PCDD/PCDF) in the Republic of Uzbekistan (Ataniyazova et al. 2001), 21$53 \mathrm{pg} / \mathrm{g}$ fat (PCDD/PCDF) in agricultural regions of southern Kazakhstan (Hooper et al. 1999), and5.9-17.1 pg/ $\mathrm{g}$ fat (PCDD/PCDF) in Spain (Schuhmacher et al. 1999). LaKind et al. (2001) reported a review of worldwide-data on C-TEQs (PCDD/PCDF) in breast milk. During the years 1970-1996, the worldwide-reported C-TEQ values were in the range of 3.1-484 $\mathrm{pg} / \mathrm{g}$ fat. The highest value was reported in Vietnam in 1970, mainly due to the spraying of Agent Orange during the Vietnam War. Despite the results indicated above, EROD-TEQ and CTEQ analyses have particular pros and cons, and thus caution should be taken in when interpreting the data. It was understandable that EROD-TEQ detected the interaction of all AhR agonists, including both identified and unknown species. On the contrary, the C-TEQ approach could not detect all AhR agonists and thus by itself is incomplete. Chemical analysis indicated the type of contaminants that could be transferred to newborns during breast feeding; however, this is not indicative of the biological or toxicological consequences of their exposure. In addition, because different studies adopt a variety of methods, different C-TEQ data are not always comparable. Although there was a very good correlation between EROD-TEQ and C-TEQ, it has been reported that using rat primary hepatocyte culture, ERODTEQ has produced data two to fivefold higher than the calculated C-TEQ (Schmitz et al. 1995; Schrenk et al. 1991; Till et al. 1997). Hence, if the data of the present study were divided by a factor of 2 or 5 , the recalculated mean levels in our region would be in the range of 29.1101.1 or $11.62-40.2 \mathrm{pg} / \mathrm{g}$ fat, respectively. These levels would be within the range of contamination reported and were comparable to those of other countries.

According to Schmid et al. (2003) concentrations of $\mathrm{PCDD} / \mathrm{F}$ in milk from farms near point sources $(0.63 \pm 0.26 \mathrm{ng} \mathrm{I-TEQ/kg} \mathrm{milk} \mathrm{fat)} \mathrm{were} \mathrm{slightly} \mathrm{but} \mathrm{sig-}$ nificantly higher in than milk from remote areas $(0.36 \pm 0.09 \mathrm{ng} \mathrm{I-TEQ} / \mathrm{kg}$ milk fat $)$. Consumer milk collected at the processing plants had intermediary levels $(0.51 \pm 0.19 \mathrm{ng} \mathrm{I}-\mathrm{TEQ} / \mathrm{kg}$ milk fat). Also in 1998, Malisch (1998) detected an increase of dioxin levels in milk and traced this back to the use of contaminated citrus pulp from Brazil. The pulp had been mixed with contaminated lime, being a waste product from a PVC production plant. The incident also had a major impact in the Netherlands where milk levels increased up to threefold. Since the contamination was only discovered after several months, most of the products had been consumed. Furthermore, the contamination could spread through the recycling of contaminated slaughterhouse offal (Hoogenboom et al. 2004). Also, the levels of PCDD/Fs in a pooled sample of breast milk were determined by Paumgartten et al. (2000). All samples, from 40 mothers living in the urban area of Rio de Janeiro County (Brazil), were collected between 4 and 6 weeks after delivery. The results showed a dioxin equivalent concentration of $8.1 \mathrm{pg} \mathrm{I}-\mathrm{TEq} / \mathrm{g}$ milk fat.

In 1994, UK scientists (Ahlborg et al. 1994) showed that the upper bound dietary intake of dioxins by the average adult consumer was estimated as $2.4 \mathrm{pg} \mathrm{TEQ} / \mathrm{kg}$ body wt/ day or $144 \mathrm{pg} \mathrm{TEQ} /$ day for a $60-\mathrm{kg}$ adult (the upper bound estimate is calculated using the assumption that where the levels of the individual congeners are below the limit of detection, they are present at the limit of detection).

In another work (Abad et al. 2002) dioxin content in the 19 milk samples (Spain) analyzed ranged from 0.09 to $0.90 \mathrm{pg} \mathrm{I-TEQ} / \mathrm{g}$ milk fat with a median of $0.35 \mathrm{pg} \mathrm{I}-\mathrm{TEQ} / \mathrm{g}$ fat and an average value of $0.36 \mathrm{pg}$ I-TEQ/g fat. These

Table 8 TEQ values (pg/g milk fat) of human breast milk collected from Hong Kong and Guangzhou (Lai et al. 2004)

\begin{tabular}{|c|c|c|c|c|c|c|}
\hline \multirow[t]{2}{*}{ Age (years) } & \multicolumn{2}{|c|}{ Number } & \multicolumn{2}{|c|}{ TEQ (pg/g fat), mean \pm SD } & \multicolumn{2}{|c|}{ TEQ (pg/g fat), median } \\
\hline & HK & GZ & HK & GZ & HK & GZ \\
\hline $21-25$ & 5 & 5 & $58.1 \pm 31.1$ & $115.8 \pm 79.6$ & 56.1 & 94.8 \\
\hline $26-30$ & 17 & 17 & $96.5 \pm 56.6$ & $202.1 \pm 217.8$ & 100.5 & 112.3 \\
\hline $31-35$ & 36 & 6 & $83.2 \pm 77$ & $98.8 \pm 49.8$ & 51.7 & 82.8 \\
\hline $33-34$ & 4 & 4 & $92.1 \pm 88.7$ & $135.7 \pm 58.2$ & 53.8 & 138 \\
\hline $35-36$ & 3 & - & $71.75 \pm 20.38$ & - & 62 & - \\
\hline
\end{tabular}

HK Hong Kong, GZ Guangzhou 
values were below the background levels (between 1.3 and $2.47 \mathrm{pg}$ I-TEQ/g fat) determined in other sites from Spain (Ramos et al. 1997). However, the values increased from 0.37 to 2.22 when co-PCBs are considered, having a median value of $0.795 \mathrm{pg}$ I-TEQ/g and an average of $1.015 \mathrm{pg} \mathrm{I-}$ $\mathrm{TEQ} / \mathrm{g}$. The results expressed in WHO-TEQ ranged from 0.11 to $1.08 \mathrm{pg} / \mathrm{g}$ fat milk (average and median of 0.43 and $0.41 \mathrm{pg} \mathrm{WHO}-\mathrm{TEQ} / \mathrm{g}$ fat, respectively) and 0.398 $2.402 \mathrm{pg} / \mathrm{g}$ fat milk including co-PCBs (average and median of 1.078 and $0.859 \mathrm{pg}$ WHO-TEQ/g fat). In general, the dioxin contamination of the milk samples studied was low and in the range of French (Vindel et al. 1999; Durand et al. 2000) and German average (Mayer 1995; Malisch et al. 1999) or some particular sites in USA (Fiedler et al. 1997b). While the 2,3,4,7,8-PeCDF was the major contributor (40\%) in Bavarian samples (Mayer 1995), 1,2,3,7,8-PeCDD and $1,2,3,6,7,8$-HxCDD contributed mainly to the total I-TEQ (25 and 22\%, respectively) in samples from USA (Fiedler et al. 1997a). In the study (Abad et al. 2002), the 2,3,4,7,8$\mathrm{PeCDF}$ was the major contributor in Spain samples (approx. $30 \%$ ), followed by $1,2,3,7,8-\mathrm{PeCDD}$ with approx. $18 \%$. So far, all samples analyzed presented dioxin content below the limit of $5 \mathrm{pg}$ I-TEQ/g fat established for its commercialization in the European countries and below the limit of $3 \mathrm{pg}$ WHO-TEQ/g proposed in the EC Regulation draft.

According to Schmid et al. (2003), the PCDD/F levels in Swiss consumer milk (pooled milk from industrial milk processing plants) were $0.51 \pm 0.19 \mathrm{ng} \mathrm{I}-\mathrm{TEQ} / \mathrm{kg}$ milk fat. This level was only slightly above those determined in milk from rural/alpine regions with an average $\mathrm{PCDD} / \mathrm{F}$ content of $0.36 \pm 0.093 \mathrm{ng} \mathrm{I}-\mathrm{TEQ} / \mathrm{kg}$ milk fat. Milk collected from the proximity of potential and former point sources had $\mathrm{PCDD} / \mathrm{F}$ levels of $0.63 \pm 0.26 \mathrm{ng} \mathrm{I}-\mathrm{TEQ} / \mathrm{kg}$ milk fat, which was slightly but significantly elevated compared to milk from remote areas: the results of a two-sample Wilcoxon rank-sum test indicate that the medians of the two datasets are statistically different $(P=0.0054)$. These levels were well in line with the most recent national average PCDD/F levels in countries of the European Union being in a range of $0.32-2.1 \mathrm{ng} \mathrm{I-TEQ} / \mathrm{kg}$ milk fat (European Commission Health and Consumer Protection Directorate-General, 2000). Based on the average level in milk from industrial processors $(0.59 \mathrm{ng} \mathrm{WHO}-\mathrm{TEQ} / \mathrm{kg}$ milk fat) and an intake of total dairy fat of $44.2 \mathrm{~g} /$ adult/day (Schlotke and Sieber 1998) the respective contribution of dairy products to the daily intake of $\mathrm{PCDD} / \mathrm{F}$ is $0.4 \mathrm{pg}$ WHO-TEQ/kg bw in Switzerland. This estimate which includes only the PCDD/F exploits $40 \%$ of the lower end of the range of the tolerable daily intake of PCDD/F and dioxin-like PCBs defined by WHO (1-4 pg WHO-TEQ/kg bw) (WHO 1998).

It also published that PCB levels have been significantly correlated with age, body mass index (BMI), male versus female gender, and the frequency of GLSCF (Great Lakes sport-caught fish) consumption (Hanrahan et al. 1999). Total dioxin, furan, and coplanar PCB TEQs have been higher in men than in women GL fish eaters (Falk et al. 1999). PCBs have been associated with decreased levels of thyroxine in men and women and decreased levels of sexhormone-binding globulin and sex-hormone-binding globulin-bound testosterone in men (Persky et al. 2001), and maternal PCB exposure has been associated with a decreased sex ratio. Turyk et al. (2006) have found that noncoplanar PCBs were higher in GLSCF consumers than in a referent population from the same geographic area, were associated with GLSCF consumption, and varied significantly by GL. Lower chlorinated dioxin and furan TEQs, and coplanar PCB TEQs were positively associated with noncoplanar PCBs but were not associated with GLSCF consumption independent of PCB level. Highly chlorinated dioxin and furan congener TEQs were not significantly associated with noncoplanar PCBs or GLSCF consumption, suggesting that participants were acquiring some of these TEQs from a source other than GLSCF. In epidemiologic studies, it may be important to include populations with high and low organochlorine levels and to consider the effects of individual congeners or groups of congeners on health outcomes. Also the findings of of other authors' studies (Falk et al. 1999) indicate that fish consumption varied with the gender among the Lake Huron subgroup. Body burden levels of dioxin, furan, and coplanar PCB total TEQs varied with the gender and lake subgroup as well. Serum levels of total dioxin TEQ also varied by lake; the Lake Huron subgroup had a significantly higher median level than the Lake Michigan subgroup. These preliminary data also demonstrated that consumption of lake trout and salmon significantly predicted serum log (total coplanar PCB) levels. In addition, lake trout consumption significantly predicted log (total furan) levels. GL sport fish consumption was not significantly correlated with total dioxin levels.

Studies of Beck et al. (1989b) and Fürst et al. (1990) indicated that dioxin levels of fish or shellfish were higher than for the other food groups, and generally, the Japanese tend to consume large amounts of fish and shellfish compared with Westerners. In the report of Toyoda (1999), the dietary daily intake of PCDDs, PCDFs, and Co-PCBs as TEQs from fish and shellfish in Japan accounted for $62.4 \%$ of the total intake. It is probable that the high intake of fish and shellfish is deeply involved in the accumulation of dioxin among the Japanese (Takekuma et al. 2004).

The levels of PCDDs/PCDFs determined in the nine butter samples were very low. The findings ranged between 0.27 and $0.65 \mathrm{pg}$ I-TEQ/g fat butter (with an average and median values of 0.47 and $0.46 \mathrm{pg} I-\mathrm{TEQ} / \mathrm{g}$ fat, respectively). The major contribution to the total I- 
TEQ were $2,3,4,7,8$-PeCDF (38\%) followed by $2,3,7,8$ TCDD and 1,2,3,7,8-PeCDD with approx.15\% each one. Similarly as milk samples, the I-TEQ values increased from 0.72 to $1.54 \mathrm{pg} / \mathrm{g}$ when co-PCBs are considered (average and median values of 1.05 and $0.97 \mathrm{pg} \mathrm{I-TEQ/g}$ fat). The values expressed in pg WHO-TEQ varied from 0.32 to $0.73 \mathrm{pg} / \mathrm{g}$ fat (average of 0.54 and a median of $0.53 \mathrm{pg} / \mathrm{g}$ fat) and between 0.76 and $1.63 \mathrm{pg} / \mathrm{g}$ fat when co-PCBs were included (average and median values of 1.12 and $1.06 \mathrm{pg} / \mathrm{g}$ fat). These results were consistent with the data reported by Fiedler et al. (1997a) or Defour et al. (1997) despite the fact that the values were slightly lower.

The patterns of dioxins and dioxin-like chemicals reflect their sources. To a specialist the measured dioxin congener patterns in blood or other tissues can be as informative as an electrocardiogram to a cardiologist. Table 9 shows patterns in patients from different dioxin exposures. The first is an American with massive PCP exposure (Ryan et al. 1987). Primarily higher chlorinated (with 5-8 chlorines) dioxins and PCDFs are noted compared to the background level of the general American population (Schecter et al. 1990). The second shows blood from an Agent Orange-exposed Vietnamese with marked elevation of TCDD, the characteristic dioxin of Agent Orange (Schecter et al. 2001b). The third shows blood from a Japanese municipal solid waste incinerator worker and primarily demonstrates elevated PCDFs compared to the general Japanese population (Schecter et al. 1999). While the congener patterns differ, the total dioxin TEQ is elevated in all three of these cases.

Table 9 Comparison of human tissue levels and toxic equivalents of dioxins and dibenzofurans from different exposures (after Schecter et al. 2006)

\begin{tabular}{|c|c|c|c|c|c|c|}
\hline \multirow{2}{*}{$\begin{array}{l}\text { Level } \\
\text { (pg/g or ppt, lipid) }\end{array}$} & \multicolumn{2}{|l|}{ Fat (USA) } & \multicolumn{2}{|c|}{ Blood (Vietnam) } & \multicolumn{2}{|c|}{ Blood (Japan) } \\
\hline & $\begin{array}{l}\text { General } \\
\text { population }^{\mathrm{a}}\end{array}$ & $\begin{array}{l}\text { PCP-exposed } \\
\text { person }^{b}\end{array}$ & $\begin{array}{l}\text { Pooled } \\
\text { Vietnamese } \\
\text { blood }^{c}\end{array}$ & $\begin{array}{l}\text { Agent } \\
\text { Orange } \\
\text { exposed }^{c}\end{array}$ & $\begin{array}{l}\text { General } \\
\text { population }^{\mathrm{d}}\end{array}$ & $\begin{array}{l}\text { Incinerator } \\
\text { worker }^{\mathrm{d}}\end{array}$ \\
\hline 2,3,7,8-Tetra-CDD & 3.6 & 33 & 2.2 & 101 & 2.6 & 6.4 \\
\hline 1,2,3,7,8-Penta-CDD & 6.6 & 70 & 3.5 & 6.1 & 8.6 & 60 \\
\hline 1,2,3,4,7,8-Неха-CDD & 8 & 698 & 3.5 & 6.4 & 0.4 & 7.7 \\
\hline 1,2,3,6,7,8-Неха-CDD & & & 7.7 & 16.5 & 0.4 & 14.5 \\
\hline 1,2,3,7,8,9-Неха-CDD & 61.2 & 346 & 2.4 & 5.4 & 0.9 & 10.6 \\
\hline 1,2,3,4,6,7,8-Hepta-CDD & NA & 15,260 & 15.4 & 37 & 0.4 & 3.1 \\
\hline OCDD & 794 & 128,913 & 114 & 212 & 0.1 & 0.1 \\
\hline 2,3,7,8-Tetra-CDF & 1.3 & ND (4.3) & 1 & 0.9 & 0.6 & 0.2 \\
\hline $1,2,3,7,8$-Penta-CDF & NA & NA & 0.5 & 0.5 & 0.2 & 0.7 \\
\hline 2,3,4,7,8-Penta-CDF & 5.6 & 50 & 6.8 & 3.1 & 7.3 & 122 \\
\hline 1,2,3,4,7,8-Неха-CDF & 6.4 & 174 & 10.1 & 7.8 & 1.1 & 27.8 \\
\hline 1,2,3,6,7,8-Неxa-CDF & 5 & & 7.8 & 4 & 0.8 & 51 \\
\hline 1,2,3,7,8,9-Неха-CDF & NA & NA & 0.5 & 0.5 & 0.1 & 34.4 \\
\hline 2,3,4,6,7,8-Неха-CDF & 1.4 & 37 & 2.1 & 1.5 & 0.4 & 5 \\
\hline 1,2,3,4,6,7,8-Hepta-CDF & 95 & 6021 & 8.6 & 10.4 & 0.1 & 15.4 \\
\hline 1,2,3,4,7,8,9-Hepta-CDF & NA & 787 & 0.8 & 0.9 & 0 & 1.1 \\
\hline OCDF & NA & 15,348 & 2.5 & 2.5 & 0 & 0 \\
\hline \multicolumn{7}{|l|}{ TEQ (pg/g or ppt, lipid) } \\
\hline 2,3,7,8-TCDD & 3.6 & 33 & 2.2 & 101 & 26 & 6.4 \\
\hline PCDD & 14 & 374 & 5 & 7 & 11 & 96 \\
\hline PCDF & 5.2 & 202 & 5.8 & 3 & 11 & 1,365 \\
\hline Total TEQ & 22.8 & 609 & 13 & 111 & 24.6 & 1,467 \\
\hline
\end{tabular}

$N D$ not detected, with detection limit; $N A$ not analyzed; $P C P$ pentachlorophenol

${ }^{\text {a }}$ Schecter et al. (1990)

b Ryan et al. (1987)

c Schecter et al. (2001a)

${ }^{d}$ Schecter et al. (1999) 


\section{Water}

The US EPA has set the allowable concentration of 2,3,7,8tetraCDD in drinking water from 0.13 to as low as $0.0013 \mathrm{pg} / \mathrm{L}$ based on estimated human cancer risks (tumor incidence risk: $0.13 \mathrm{pg} / \mathrm{L}$ for $10^{-5}, 0.0013 \mathrm{pg} / \mathrm{L}$ for $10^{-7}$ ), respectively (US EPA 1984). The maximum contaminant level (MCL), based on the tolerable daily intake (TDI) of $10 \mathrm{pg} \mathrm{TEQ} / \mathrm{kg} /$ body weight/day, as well as the maximum contaminant level goal (MCLG), have been set at $30 \mathrm{pg}$ TEQ/L and 0 pg TEQ/L, respectively (US EPA 2001).

PCDD/Fs, and co-PCBs' analyses in raw and treated water throughout Japan were implemented to identify the concentration and homologue patterns of dioxins before and after the water treatment process (Kim et al. 2002). In 40 surface water and 5 ground water treatment plants, the dioxin-removing efficiency and the extent of influence chlorination has on dioxins' increase in drinking water were also studied. Raw water and treated water were sampled twice-during summer and winter. The mean concentration in raw water and treated water of dioxins was $56.45 \mathrm{pg} / \mathrm{L}(0.15 \mathrm{pg}$ WHO-TEQ/L) and $4.24 \mathrm{pg} / \mathrm{L}$ (0.019 pg WHO-TEQ/L), respectively. Location of water treatment plants not only significantly influenced the concentration level of dioxins but also resulted in different homologue patterns of dioxins. Levels of dioxins in ground water were much less than that of surface water in both raw and treated water. This study showed that most dioxin congeners were well removed (87\% removal efficiency) by water treatment. However, in some water treatment plants, the level of TeCDFs (pg WHO-TEQ/L) increased as a result of chlorination. This result is in agreement with that of a previous result and most of dioxins and dioxin-like compounds can be removed by drinking water treatment such as coagulation, sedimentation and filtration (Smirnov et al. 1996). Congener distributions of $\mathrm{PCDD} / \mathrm{Fs}$ and co-PCBs for raw water are shown in Table 10. As expected, concentration in ground water, compared to total average concentration, was low, $3.48 \mathrm{pg} / \mathrm{L}(6.2 \%$ of total dioxins), whereas the concentration in surface water was much higher, $63.07 \mathrm{pg} / \mathrm{L}$. The average dioxin concentration in ground water is about four times lower than that of the 25 sampling sites reported in 1999 (Tokuda 1999). The average concentration in surface water was lower than that in Germany and England (Götz et al. 1994).

Table 10 Congener distribution of PCDD/Fs and co-PCBs in raw water (after Kim et al. 2002)

\begin{tabular}{|c|c|c|c|c|c|c|}
\hline Congener & $\begin{array}{l}\text { Surface } \\
\text { water }^{\mathrm{a}} \\
(\mathrm{pg} / \mathrm{L})\end{array}$ & $\begin{array}{l}\text { Ground } \\
\text { water }^{\mathrm{a}} \\
(\mathrm{pg} / \mathrm{L})\end{array}$ & $\begin{array}{l}\text { Total } \\
\text { average }^{\mathrm{b}} \\
(\mathrm{pg} / \mathrm{L})\end{array}$ & Percentage $^{\mathrm{c}}(\%)$ & $\begin{array}{l}\text { Total } \\
\text { average }^{b} \\
(p g-T E Q / L)\end{array}$ & Percentage $^{\mathrm{c}}(\%)$ \\
\hline TeCDDs & 10.97 & 0.66 & 9.83 & 17.41 & 0.0083 & 5.63 \\
\hline PeCDDs & 1.81 & 0.14 & 1.62 & 2.87 & 0.0294 & 19.94 \\
\hline HxCDDs & 1.20 & 0.05 & 1.07 & 1.90 & 0.0201 & 13.64 \\
\hline HpCDDs & 3.64 & 0.03 & 3.24 & 5.74 & 0.0153 & 10.38 \\
\hline OCDD & 26.71 & 0.11 & 23.75 & 42.07 & 0.0024 & 1.63 \\
\hline Total PCDD ${ }^{\mathrm{d}}$ & 44.23 & 0.99 & 39.51 & 69.99 & 0.0755 & 51.22 \\
\hline TeCDFs & 1.23 & 0.13 & 1.10 & 1.95 & 0.0090 & 6.11 \\
\hline PeCDFs & 0.77 & 0.07 & 0.69 & 1.22 & 0.0240 & 16.28 \\
\hline HxCDFs & 0.86 & 0.04 & 0.77 & 1.36 & 0.0246 & 16.69 \\
\hline HpCDFs & 0.99 & 0.01 & 0.88 & 1.56 & 0.0048 & 3.25 \\
\hline OCDF & 0.88 & ND & 0.79 & 1.40 & 0.0001 & 0.07 \\
\hline Total PCDF ${ }^{\mathrm{d}}$ & 4.73 & 0.25 & 4.23 & 7.49 & 0.0625 & 42.40 \\
\hline Non-ortho PCBs & 1.04 & 0.10 & 0.93 & 1.65 & 0.0078 & 5.29 \\
\hline Mono-ortho PCBs & 12.98 & 2.15 & 11.78 & 20.87 & 0.0016 & 1.09 \\
\hline Total Co $\mathrm{PCB}^{\mathrm{d}}$ & 14.02 & 2.25 & 12.71 & 22.52 & 0.0094 & 6.38 \\
\hline Total dioxins ${ }^{\mathrm{e}}$ & 63.07 & 3.49 & 56.45 & 100.00 & 0.1474 & 100.00 \\
\hline
\end{tabular}

\footnotetext{
${ }^{a}$ Surface water $(\mathrm{pg} / \mathrm{L})$ (resp. ground water $(\mathrm{pg} / \mathrm{L})$ are the average dioxin concentrations at 40 surface water plants (resp. five ground water plants)

b Total average (pg/L) (resp. total average (pg-TEQ/L) are the average dioxin concentration at 45 water plants

${ }^{c}$ Percentage (\%) means the ratio of homologues to total dioxins

d Total PCDDs (resp. total PCDFs, resp. total Co-PCBs) are the sum of tetra to octra CDD (resp. sum of tetra to octa CDF and resp. sum of nonortho PCBs and mono-ortho PCBs)

e Total dioxins are the sum of total PCDDs, total PCDFs and total Co-PCBs
} 
Air

It should be noted that monitoring of dioxins plays an important role in public and sanitary decisions. In particular, the presence and trend of these pollutants in the atmosphere has been the subject of many environmental studies performed all over the world (Abad et al. 2004). For instance, Fiedler et al. (2000) reported compiled data from Germany in 1993. The levels in rural areas ranged from 25 to $70 \mathrm{fg} \mathrm{I-TEQ} / \mathrm{m}^{3}$, whereas those in urban areas varied between 70 and $350 \mathrm{fg} \mathrm{I-TEQ} / \mathrm{m}^{3}$, and levels close to source oscillated between 350 and $1,600 \mathrm{fg} \mathrm{I-TEQ} / \mathrm{m}^{3}$. Previously, concentrations over 1,068 ambient air samples from some sites were characterized in several cases by higher concentrations and larger ranges. Stenhouse et al. (1998) reported PCDD/PCDF levels in ambient air in Slovakia collected from 15 sampling locations with maximum levels, expressed in geometrical means, between 40 and $130 \mathrm{fg} \mathrm{I-TEQ} / \mathrm{m}^{3}(n=113)$. Bolt and de Jong (1993) reported levels of PCDD/Fs from The Netherlands. Background levels between 10 and $15 \mathrm{fg} \mathrm{I-}$ $\mathrm{TEQ} / \mathrm{m}^{3}$ were determined, whereas levels in air around a municipal waste incinerator ranged from $15 \pm 5$ to $125 \pm 25 \mathrm{fg} \mathrm{I}-\mathrm{TEQ} / \mathrm{m}^{3}$ in the deposition area. The US EPA reported the results after 2 years of the implementation of the National Dioxin Air Monitoring Network (NDAMN). Values in samples collected in rural areas and national parks were not higher than $25 \mathrm{fg}$ WHO98-TEQDF $/ \mathrm{m}^{3}$ (Cleverly et al. 2000, 2001). Sin et al. (2002) reported the results of 27 samples collected in six locations in Hong Kong. Levels of PCDDs/PCDFs ranging from 30 to $430 \mathrm{fg} \mathrm{I}-\mathrm{TEQ} / \mathrm{m}^{3}$ were determined in winter, whereas concentrations from 18 to $25 \mathrm{fg} \mathrm{I}-\mathrm{TEQ} / \mathrm{m}^{3}$ were calculated in summertime, which also reflects the potential influence of the season parameters affecting the dioxin assessment in the ambient air.

Abad et al. (2004) reported the results of an assessment of dioxin levels in ambient air in samples collected in the four provinces of Catalonia (Spain). The study includes compiled data of more than 133 samples collected in 28 different sites (rural, urban, suburban and industrial) between 1994 and 2002. The levels revealed a variable content of PCDDs/PCDFs depending both on the area and the contamination source. Thus, concentrations from 16 to $954 \mathrm{fg} \mathrm{I}-\mathrm{TEQ} / \mathrm{Nm}^{3}$, with a mean value of $180 \mathrm{fg} \mathrm{I}-\mathrm{TEQ} /$ $\mathrm{Nm}^{3}$, were determined in industrial areas. The levels found in urban and suburban sites varied from 10 to $357 \mathrm{fg} \mathrm{I}$ $\mathrm{TEQ} / \mathrm{Nm}^{3}$, with a mean value of $80 \mathrm{fg} \mathrm{I}-\mathrm{TEQ} / \mathrm{Nm}^{3}$. The lowest concentrations were found in rural areas, ranging


$\mathrm{TEQ} / \mathrm{Nm}^{3}$. These results were comparable to those reported in other works (Fiedler et al. 2000; Bolt and de Jong 1993; Cleverly et al. 2001).
As part of the project, levels of samples collected in parallel using two different samplers, a total suspended particulate (TSP) sampler and $\mathrm{PM}_{10}$ sampler, were compared. The results of 11 different campaigns indicated that both methods are comparable and no significant differences were determined (Table 11) (Abad et al. 2004).

Chang et al. (2004) measured PCDD/F concentrations in tunnel air and vehicle exhaust. The results indicate that the tunnel air had a PCDD/F TEQ concentration of about two times as high as that of outside air (47.3 and $57.1 \mathrm{fg}-\mathrm{I}-$ $\mathrm{TEQ} / \mathrm{m}^{3}$ for tunnel air vs. $37.1 \mathrm{fg}-\mathrm{I}-\mathrm{TEQ} / \mathrm{m}^{3}$ and $23.3 \mathrm{fg}-\mathrm{I}-$ $\mathrm{TEQ} / \mathrm{m}^{3}$ for outside air, respectively). This provides the direct evidence that PCDD/F compounds are emitted from the combustion processes in gasoline- and diesel-fueled engines. According to the tunnel study, the emission factors ranged from 5.83 to $59.2 \mathrm{pg}$ I-TEQ $/ \mathrm{km}$ for gasoline vehicles and 23.32 to $236.65 \mathrm{pg}$ I-TEQ $/ \mathrm{km}$ of diesel vehicles. This indicates that the dioxin emission factor in Taiwan is lower than that measured in USA, Norway and Germany (Table 12). When the speed of the diesel vehicle was set at $40 \mathrm{kmph}$, the dioxin concentration emitted from diesel vehicle was $278 \mathrm{pg} / \mathrm{m}^{3}\left(6.27 \mathrm{pg}-\mathrm{I}-\mathrm{TEQ} / \mathrm{m}^{3}\right)$ from tailpipe testing. However, when the diesel vehicle was idled, the dioxin concentration increased greatly to $4,078 \mathrm{pg} / \mathrm{m}^{3}$ (41.9 $\left.\mathrm{pg}-\mathrm{I}-\mathrm{TEQ} / \mathrm{m}^{3}\right)$. From the results of tunnel air sampling, the PCDDyFs emission from automobiles in Taiwan was estimated as $3.69 \mathrm{~g}$ I-TEQ per year.

Table 11 Comparison of individual 2,3,7,8-PCDDs/PCDFs determined by TSP and $\mathrm{PM}_{10}$ samplers (Abad et al. 2004)

\begin{tabular}{lcc}
\hline Compounds & $\begin{array}{l}\text { Concentration } \\
\left(\mathrm{fg} / \mathrm{Nm}^{3}\right)\end{array}$ & $\begin{array}{c}\text { Concentration } \\
\left.\text { (fg/ sm } / \mathrm{Nm}^{3}\right) \text { PM }\end{array}$ \\
\hline $2,3,7,8-\mathrm{TDCF}$ & 54.70 & sampler \\
$1,2,3,7,8-\mathrm{PeCDF}$ & 11.02 & 47.44 \\
$2,3,4,7,8-\mathrm{PeCDF}$ & 22.43 & 9.07 \\
$1,2,3,4,7,8-\mathrm{HxCDF}$ & 54.56 & 20.59 \\
$1,2,3,6,7,8-\mathrm{HxCDF}$ & 23.81 & 56.41 \\
$2,3,4,6,7,8-\mathrm{HxCDF}$ & 30.39 & 21.92 \\
$1,2,3,7,8,9-\mathrm{HxCDF}$ & 1.37 & 30.49 \\
$1,2,3,4,6,7,8-\mathrm{HpCDF}$ & 123.19 & 1.31 \\
$1,2,3,4,7,8,9-\mathrm{HpCDF}$ & 12.80 & 115.45 \\
OCDF & 118.94 & 13.94 \\
$2,3,7,8-\mathrm{TCDD}$ & 2.33 & 105.77 \\
$1,2,3,7,8-\mathrm{PeCDD}$ & 6.52 & 1.89 \\
$1,2,3,4,7,8-\mathrm{HxCDD}$ & 6.97 & 6.52 \\
$1,2,3,6,7,8-\mathrm{HxCDD}$ & 14.24 & 6.08 \\
$1,2,3,7,8,9-\mathrm{HxCDD}$ & 24.65 & 17.67 \\
$1,2,3,4,6,7,8-\mathrm{HpCDD}$ & 201.66 & 21.99 \\
OCDD & 645.36 & 177.97 \\
\hline
\end{tabular}


Table 12 Dioxin emission factors from vehicles in different countries (after Chang et al. 2004)

\begin{tabular}{|c|c|c|c|c|c|}
\hline Study and year & Country & Sampling & Vehicles & $\begin{array}{l}\text { EF1 } \\
(\mathrm{pg} \mathrm{I-TEQ/km)}\end{array}$ & $\begin{array}{l}\text { EF2 } \\
(\text { pg I-TEQ/L) }\end{array}$ \\
\hline \multirow[t]{3}{*}{ CARB (1987) } & \multirow[t]{3}{*}{ USA } & \multirow[t]{3}{*}{ Tailpipe } & Leaded & 203 & 1,794 \\
\hline & & & Diesel & 380 & 5,904 \\
\hline & & & Diesel & 4,900 & 27,440 \\
\hline \multirow[t]{2}{*}{ Marklund et al. (1987) } & \multirow[t]{2}{*}{ Sweden } & \multirow[t]{2}{*}{ Tailpipe } & Unleaded & $<13$ & - \\
\hline & & & Leaded & $20-220$ & - \\
\hline Bingham et al. (1989) & New Zealand & Tailpipe & Leaded & $15-39$ & - \\
\hline Marklund et al. (1990) & Sweden & Tailpipe & Unleaded & 0.36 & - \\
\hline \multirow[t]{5}{*}{ Hagenmaier et al. (1990) } & \multirow[t]{5}{*}{ Germany } & \multirow[t]{5}{*}{ Tailpipe } & Unleaded & 5.1 & 50.7 \\
\hline & & & Unleaded & 0.7 & 7.2 \\
\hline & & & Leaded & 108.3 & 1,083 \\
\hline & & & Diesel & 2.4 & 23.6 \\
\hline & & & Diesel & 35 & 70 \\
\hline \multirow[t]{2}{*}{ Oehme et al. (1991) } & \multirow[t]{2}{*}{ Norway } & \multirow[t]{2}{*}{ Tunnel } & Leaded/unleaded & $28-520$ & - \\
\hline & & & Diesel & $720-9,500$ & - \\
\hline \multirow[t]{3}{*}{ Wevers et al. (1992) } & \multirow[t]{3}{*}{ Belgium } & \multirow[t]{3}{*}{ Tunnel } & Leaded & 1641 & - \\
\hline & & & Unleaded & 10 & - \\
\hline & & & Diesel & 35.7 & - \\
\hline Hagenmaier et al. (1995) & Germany & Tailpipe & Diesel & - & 10 \\
\hline Buhler and Greiner (1996) & Germany & Tailpipe & Diesel & 14 & 77 \\
\hline Gertler et al. (1998) & USA & Tunnel & Diesel & 29 & - \\
\hline Ryan and Gullet (2000) & USA & Tailpipe & Diesel & 29-106 & - \\
\hline \multirow[t]{2}{*}{ Chang et al. (2004) } & \multirow[t]{2}{*}{ Taiwan } & \multirow[t]{2}{*}{ Tunnel } & Unleaded & 22.9 & 229.3 \\
\hline & & & Diesel & 91.7 & 550.4 \\
\hline
\end{tabular}

\section{Soil}

According to Lohmann and Jones (1998), PCDD/F concentrations for the total sum of TEQ are typically as follows: remote $<10 \mathrm{fg}$ I-TEQ $\mathrm{m}^{-3}$ ); rural $\sim 20-50 \mathrm{fg}$ ITEQ $\mathrm{m}^{-3}$ ); and urban/industrial $\sim 100-400 \mathrm{fg}^{\mathrm{I}-\mathrm{TEQ} \mathrm{m}^{-3}}$. Concentrations measured in Lisbon are comparable to those found in rural and uncontaminated urban areas: $83 \%$ of PCDD/PCDF concentrations in this region range from 10 to $100 \mathrm{fg} \mathrm{I}^{\mathrm{T}} \mathrm{TEQ} \mathrm{m}^{-3}$. On the other hand, in Porto $77 \%$ of samples collected are in the 40 to $400 \mathrm{fg}^{\mathrm{I}}$-TEQ $\mathrm{m}^{-3}$ range, approximately four times higher than the levels for the Lisbon region. Levels measured in Porto are consistent with data published for Barcelona, on the NE coast of the Iberian Peninsula, where the reported maximum concentrations were in the range of 600 to $800 \mathrm{fg}^{\mathrm{I}-\mathrm{TEQ} \mathrm{m}^{-3}}$ (Abad et al. 2004). Several studies performed in different airsheds (Hippelein et al. 1996; Fiedler et al. 1997a) have shown that atmospheric levels of PCDD/PCDF follow a typical seasonal variation characterized by higher concentrations during winter when compared with typical summer concentrations. This seasonal pattern can be explained by the intensification of the operation of diverse combustion sources during winter as well as by the more frequent presence of thermal inversion layers at the surface level during winter. These inversions cause a significant increase of atmospheric concentrations when pollutants are emitted at low levels below the thermal inversion layer.

According to Coutinho et al. (2006) interpretation of temporal trends of atmospheric dioxin levels in the region of Porto (Portugal) shows the contribution that medical waste incinerators, without any air pollution control devices, might have in the deterioration of air quality in urban areas. Prior to the winter of 2001-2002, winter levels in Porto were approximately three to four times higher than summer levels. Afterwards, it is possible to observe a significant decrease of mean concentrations of atmospheric $\mathrm{PCDD} / \mathrm{F}$. The mean value ( $37 \mathrm{fg} \mathrm{I}^{\mathrm{T}} \mathrm{TEQ} \mathrm{\textrm {m } ^ { - 3 }}$ ) and concentration range (13-42 fg I-TEQ $\mathrm{m}^{-3}$ ) for Summer 2002 are the lowest recorded in this region, followed by Summer 2003 (mean $50 \mathrm{fg} \mathrm{I}^{-T E Q ~ \mathrm{~m}^{-3}}$, range 9.8-172 fg I-TEQ $\mathrm{m}^{-}$ ${ }^{3}$ ). The decrease of atmospheric concentrations of PCDD/F was more evident during winter time: PCDD/F levels showed a reduction by a factor of 2 , from average levels typically above $300 \mathrm{fg}$ I-TEQ $\mathrm{m}^{-3}$ to values between 150 and $200 \mathrm{fg}^{\mathrm{I}}$-TEQ $\mathrm{m}^{-3}$.

A major seasonal pollution source of atmospheric PCDD/F levels in the region may also be the household 
wood burning for heating in winter. Burning woods at low temperatures, with low burning efficiency, plus burning of wood treated with chlorinated phenols (added as a preservative) woods may increase PCDD/PCDF emissions (Dyke et al. 1997).

\section{Sediments}

A potential natural formation mechanism for chlorinated organic compounds is biochemical synthesis. Living organisms are capable of synthesizing a variety of halogenated compounds (Gribble 1994). Subsequent biochemical (enzymatic) and chemical reactions may lead to the transformation of suitable precursors into more complex structures. Enzymatic and photochemical formation of $\mathrm{PCDD} / \mathrm{Fs}$ from precursors has been demonstrated under laboratory conditions (Svenson et al. 1989; Vollmuth et al. 1994). Evidence for natural formation of di- to tetrachlorinated dibenzo- $p$-dioxins and dibenzofurans in forest soils has also been presented (Hoeksta et al. 2000).

Isosaari et al. (2002) reported that PCB sum concentrations in sediments (Lake Ahmasjärvi, Finland) ranged from 50 to $2,540 \mathrm{ng} / \mathrm{kg} \mathrm{dw}$ (Table 13). They concluded that the PCB sum concentrations in sediments were in the same range as those measured in lake sediments from northern Finland $(3.0-5.6 \mathrm{ng} / \mathrm{kg} \mathrm{dw}$ ) (Vartiainen et al. 1997), southern Finland (sum of 8 congeners $5-20 \mathrm{ng} / \mathrm{kg}$ dw) (Lampi et al. 1992) and Canada (2.4-39 ng/kg dw) (Muir et al. 1996). The cleanest subsamples taken from Lake Ahmasjärvi were as clean as the lake sediments from Antarctica (Fuoco et al. 1994).

In other studies, PCB concentrations in the old sediment deposits have been below detection limits (Muir et al.
1996; Vartiainen et al. 1997). The production of PCBs on an industrial scale started in 1929 (Bernes 1998), and detectable concentrations typically appear only after the 1940s. It is possible that ambient air contaminates sediment samples with lower chlorinated PCBs, especially. Therefore, more data are needed to validate the presence of PCBs in deposits that are thousands of years old. Isosaari et al. (2002) reported that PCDD/F sum concentrations at the depths of $112-400 \mathrm{~cm}$ were $4.91-59.2 \mathrm{ng} / \mathrm{kg} \mathrm{dw}(1.99$ $8.44 \mathrm{ng} / \mathrm{kg} \mathrm{dw}$ of 2378 -substituted PCDD/Fs). Historical dioxin background in about 8,000-year old sediment cores from an inland sea in Japan was $52 \mathrm{ng} / \mathrm{kg}$ dw for 1234679 HpCDD and $320 \mathrm{ng} / \mathrm{kg} \mathrm{dw}$ for OCDD (Hashimoto et al. 1990). Other clearly pre-industrial data are available on tissue samples of Eskimos who were exposed to incomplete combustion products in their lives about 400 years ago. In these tissues, the levels of the studied tetra- to hexa-CDD/ Fs were below detection limits (Schecter et al. 1988).

Their results (Isosaari et al. 2002) support the theory of natural formation of PCDD/Fs. However, it must be noted that the originally formed $\mathrm{PCDD} / \mathrm{F}$ profile might have become transformed on the way to the sink or in the sink, resulting in a previously addressed discrepancy between PCDD/F homologue patterns of sources and sinks (DuarteDavidson et al. 1997; Wagrowski and Hites 2000). The mechanisms of wet and dry deposition of PCDD/Fs and decomposition of the lower chlorinated congeners in the atmosphere contribute to a selective enrichment of OCDD in soils and sediments (Koester and Hites 1992). Overall concentrations may also increase. Hypotheses have been proposed to show how PCDD/Fs would accumulate in soil if there were no losses (Duarte-Davidson et al. 1997). Local and temporal changes in PCDD/F accumulation rate,

Table 13 A summary of PCDD/F and PCB sum concentrations (ng/kg dw), (Isosaari et al. (2002)

\begin{tabular}{|c|c|c|c|c|c|}
\hline Depth $(\mathrm{cm})$ & $\operatorname{Age}^{a}(a)$ & $\begin{array}{l}\text { Sum of } \\
\text { PCBs }\end{array}$ & $\begin{array}{l}\text { Sum of } \\
\text { PCDD/Fs }\end{array}$ & $\begin{array}{l}\text { Sum of } \\
2,3,7,8-\mathrm{PCDD} / \mathrm{Fs}\end{array}$ & $\overline{\text { WHO-TEQ }^{c}}$ \\
\hline $0-11$ & $0-311$ & 380 & 84.3 & 35.0 & 1.18 \\
\hline $11-23$ & $311-622$ & 554 & 40.7 & 6.63 & 0.56 \\
\hline $23-34$ & $622-932$ & 2,530 & 32.7 & 11.1 & 1.70 \\
\hline $68-79$ & $1,864-2,175$ & 674 & 28.6 & 4.02 & 0.80 \\
\hline $112-124$ & $3,107-3,418$ & 630 & 19.4 & 4.07 & 0.38 \\
\hline $124-135$ & $3,418-3,728$ & 750 & 32.8 & 8.44 & 1.62 \\
\hline $146-157$ & $4,039-4,350$ & 1,090 & 59.2 & 7.09 & 0.88 \\
\hline $227-239$ & $6,214-6,525$ & 1,030 & 11.8 & 4.91 & 1.00 \\
\hline $310-321$ & $7,930-7,991$ & 32.0 & 4.91 & 2.60 & 0.41 \\
\hline $390-400$ & $8,370-8,425$ & 150 & 5.72 & 1.99 & 0.23 \\
\hline
\end{tabular}

a Calibrated age in years before 1999

b Sum of 25 mainly di-ortho PCB congeners (IUPAC 18, 28, 33, 47, 49, 51, 52, 60, 66, 74, 99, 101, 110, 122, 128, 138, 141, 153, 170, 180, 183, 187, 194, 206, 209), 8 mono-ortho congeners (IUPAC 105, 114, 118, 123, 156, 167, 189), and 3 non-ortho congeners (IUPAC 77, 126, 169)

c WHO-TEQ based on toxicity equivalent factors (TEFs) for PCDD/Fs 
and the resulting concentrations in sediments, could be associated with the extent of physical and biological turbulence (for a review, see Fletcher and McKay 1993). Thus, the usefulness of a sediment core as evidence regarding which congeners have been formed and to what extent, and when, is only of a descriptive nature.

\section{Occupational exposure}

Some human subpopulations are at risk of either continuous or intermittent exposure to relatively high levels of PCDFs and PCDDs, which may result in adverse health effects. Workers engaged in the production, use, or destruction of materials containing these chemicals or their precursors may be subject to such risks (Beck et al. 1989a; Päpke et al. 1992). Dermal and inhalation are exposure routes particularly relevant to production and usage of agricultural and industrial products. In the recent past, discrete exposures to high levels of these compounds have occurred through industrial accidents (e.g., Seveso, Italy in 1976) and improper disposal of industrial waste (e.g., Times Beach, Missouri, 1982). Subsistence and recreational fishermen (Svensson et al. 1991) may have rich dietary exposure to these compounds, due to their bioconcentration in fish; and subsistent farmers living near point sources of contamination, such as incinerators, may experience similar risks of dietary exposure (Wevers et al. 1993). Airborne fly ash particles emitted from incineration combustion are of respiratory size (Stevens and Swackhamer 1989; Fiedler 1996) and could deposit in the airways of the lung. Airborne dust particulates and volatile TCDD are also a concern for pulmonary absorption (Goldfarb and Harrad 1991). The major contaminant-adsorbing surfaces of soil consist of organic matter and clay and these are predominant in the respirable fraction of soil (Morrill et al. 1982). Even though relatively low ambient levels of PCDDs and PCDFs are found in air, soil, and sediment, these compounds because of their stable and persistent lipophilic nature bioconcentrate in the food chain. Most of the apparent exposure of the general human population to PCDDs and PCDFs occurs through dietary consumption (Winters et al. 1994), with daily human exposure to TCDD through ingestion estimated to be $0.1-0.3 \mathrm{pg} \mathrm{TCDD} / \mathrm{kg} / \mathrm{day}$ (Fürst et al. 1991).

For example, in Table 14 the emission factors calculated from the measurements are presented. The highest emission factor value is calculated for plants: 7, 9 and 12 (foundries of cast iron, secondary aluminium production-aluminium scrap melting-electric furnace and secondary aluminium production -aluminium scrap and cans melting). Emission factors obtained for iron ore sintering
Table 14 Emission factors estimated during the measurement program (Grochowalski et al. 2006)

\begin{tabular}{lll}
\hline Type of activity & $\begin{array}{l}\text { Emission factors } \\
\mu \mathrm{g} \mathrm{I}-\mathrm{TEQ} / \mathrm{mg} \\
\text { of product }\end{array}$ & $\begin{array}{l}\text { Emission factors } \\
\mu \mathrm{g} I-\mathrm{TEQ} / \mathrm{mg} \\
\text { of product } \\
\text { (Inventory of }\end{array}$ \\
& & $\begin{array}{l}\text { Dioxin and Furan } \\
\text { Releases in Poland, }\end{array}$ \\
Report 2002)
\end{tabular}

\begin{tabular}{|c|c|c|}
\hline \multicolumn{3}{|l|}{ Iron and steel metallurgy plants } \\
\hline Iron ore sintering plant & $1.47,1.10$ & 5 \\
\hline Primary Iron production-Blast Furnace $(\mathrm{BF})$ & 0.01 & $0.03-0.13$ \\
\hline $\begin{array}{l}\text { Primary and secondary steel production-Basic } \\
\text { Oxygen Furnace (BOF) }\end{array}$ & 0.020 & $0.5-10$ \\
\hline Iron casting-hot air cupola (good APCs) ${ }^{a}$ & $0.06,4.11$ & $0.03-10$ \\
\hline Iron casting-gas rotary kiln & 0.02 & 4.3 \\
\hline $\begin{array}{l}\text { Secondary steel production, steel scrap } \\
\text { melting-electric arc furnaces }\end{array}$ & $0.62,0.02^{\mathrm{b}}$ & 5 \\
\hline Steel casting-electric arc furnace & 0.03 & 1.0 \\
\hline \multicolumn{3}{|l|}{ Non-ferrous metallurgy plants } \\
\hline $\begin{array}{l}\text { Primary copper production from concentrate } \\
\text { with } \mathrm{H}_{2} \mathrm{SO}_{4} \text { production; copper slag recycling }\end{array}$ & $0.005,0.004,0.002$ & 0.01 \\
\hline Copper scrap melting & 0.007 & 50 \\
\hline $\begin{array}{l}\text { Secondary aluminium production, } \\
\text { aluminium scrap and cans melting }\end{array}$ & $8.65,3.05,1.69,0.34$ & 150 \\
\hline Primary zinc production & 0.12 & $0.15-2.4$ \\
\hline Zinc casting & 0.02 & Not data available \\
\hline
\end{tabular}

a Air pollution control systems

${ }^{\mathrm{b}}$ Only secondary off gas was measured in the plants 
indicate that the previous data $(5 \mu \mathrm{g}$ I-TEQ/t) have been overestimated.

It also has been shown for primary iron (Blast Furnace), as well as for primary and secondary steel production. That indicates that secondary aluminium production is the most significant dioxin source if calculated as an emission factor value; however, iron ore sintering plants are operated in much higher product mass efficiency and hence this process is the major source to release dioxins, PCB and HCB pollution to the environment. The level of dioxin emission from secondary aluminium production depends on the raw material composition and the applied APCS (Iron castinghot air cupola). The default emission factor proposed to apply previously was $150 \mu \mathrm{g}$ I-TEQ/t of aluminium with an uncertainty range of $50-450 \mu \mathrm{g}$ I-TEQ/t. The Standardized Toolkit (UNEP 2003) does not provide any default emission factors for aluminium casting. As pure ingots are used for the production, the emission factors are estimated to be considerably lower than the electric furnace (EF) for secondary aluminium production. The toolkit applies an EF of $1 \mu \mathrm{g} \mathrm{I-TEQ/t} \mathrm{for} \mathrm{zinc} \mathrm{and} \mathrm{zinc} \mathrm{casting} \mathrm{in}$ furnaces without air pollution control systems (APCS) and 0.3 for casting of zinc alloys. The data obtained from the European Dioxin Inventory (Quaß 1997) applies emission factors for secondary zinc in the range of $0.15-2.4 \mu \mathrm{g} \mathrm{I}-$ $\mathrm{TEQ} / \mathrm{t}$.

\section{Conclusion}

In numerous investigations it was shown that food is the main route of non-occupational human exposure to polychlorinated dibenzo-p-dioxins (PCDDs) and PCDFs. It is also known that animal products like meat, fish, milk and milk products are largely contributing to the human burden as PCDD/Fs are bioaccumulated because of their lipophilicity and their low biodegradability. Also, PCDDs and PCDFs can be formed as unwanted by-products by many anthropogenic processes and their presence in the atmosphere stems from several industrial activities which include, for instance, a variety of thermal processes such as waste management plants, cement kiln plants, sintering plants and other diffuse sources Furthermore, once released into the atmosphere, these toxicants can be transported far away from their original sources, and as a result, their presence can be determined in remote areas. In this sense, great efforts to increase the knowledge about these pollutants have been taken and stringent regulations aiming to protect public health have already been established.

Thus, monitoring of dioxins plays an important role in public and sanitary decisions. In particular, the presence and trend of these pollutants in the atmosphere, food, soil and human samples have been the subject of many envi- ronmental studies performed all over the world (for a review, see Parzefall 2002).

\section{References}

Abad E, Llerena JJ, Sauló J, Caixach J, Rivera J (2000a) Comprehensive study on dioxin contents in binder and anticaking agent feed additives. Organohalog Compd 46:439-442

Abad E, Sauló J, Caixach J, Rivera J (2000b) Evaluation of a new automated cleanup system for the analysis of polychlorinated dibenzo- $p$-dioxins and dibenzofurans in environmental samples. J Chromatogr 893:383-391

Abad E, Llerena J, Saulǒ J, Caixach J, Rivera J (2002) Study on PCDDs/PCDFs and co-PCBs content in food samples from Catalonia (Spain). Chemosphere 46:1435-1441

Abad E, Caixach J, Rivera J, Gustems L, Massagué G, Puig O (2004) Temporal trends of PCDDs/PCDFs in ambient air in Catalonia (Spain). Sci Total Environ 334-335:279-285

Ahlborg UG, Becking GC, Birnbaum LS, Brouwer A, Derks HJGM et al (1994) Toxic equivalency factors for dioxin-like PCBs. Chemosphere 28:1049-1067

Alder L, Beck H, Mathar W, Palavinskas R (1994) PCDDs, PCDFs, $\mathrm{PCBs}$, and other organochlorine compounds in human milk-levels and their dynamics in Germany. Organohalog Compd 21:39-44

Aoki A (2001) Polychlorinated biphenyls, polychloronated dibenzo$p$-dioxins, and polychlorinated dibenzofurans as endocrine disrupters - what we have learned from Yusho Disease. Environ Res Sec A 86:2-11

Ataniyazova OA, Baumann RA, Liem AKD, Mukhopadhyay UA, Vogelaar EF, Boersma ER, (2001) Levels of certain metals, organochlorine pesticides and dioxins in cord blood, maternal blood, human milk and some commonly used nutrients in the surroundings of the Aral sea (Karakalpakstan, republic of Uzbekistan). Acta Pediatr 90:801-808

ATSDR (2000) Toxicological profile for polychlorinated biphenyls (update). Agency for Toxic Substances and Disease Registry, US Public Health Service, Atlanta, GA, USA

Baars AJ, Bakker BI, Baumann RA, Boon PE, Freijer JI, Hoogenboom LAP et al (2004) Dioxins, dioxin-like PCBs and nondioxin-like PCBs in foodstuffs: occurrence and dietary intake in The Netherlands. Toxicol Lett 151:51-61

Ballschmiter K, Zell M (1980) Analysis of polychlorinated biphenyls (PCB) by glass capillary gas chromatography. Fresenius Z Anal Chem 302:20-31

Beck H, Eckart K, Mathar W, Wittkowski R (1989a) Levels of PCDDs and PCDFs in adipose tissue of occupational exposed workers. Chemosphere 18:507-516

Beck H, Eckart K, Mathar W, Wittkowski R (1989b) PCDD and PCDF body burden from food intake in the Federal Republic of Germany. Chemosphere 18:417-424

Beck H, Drob A, Kleeman WJ, Mathar W (1990) PCDD and PCDF concentrations in different organs from infants. Chemosphere 20:903-910

Beck H, Dross A, Mathar W (1994) PCDD and PCDF exposure and levels in humans in Germany. Environ Health Perspect 102:173185

Beebe L, Park SS, Anderson LM (1990) Differential enzyme induction of mouse liver and lung following a single low or high dose of 2,3,7,8-tetrachlorodibenzo- $p$-dioxin (TCDD). J Biochem Toxicol 5:211-219

Bencko V, Skulová Z, Kreemerová M, Liem DAK (1998) Selected polyhalogenated hydrocarbons in breast milk. Toxicol Lett 97:341-345 
Beretta M, Dick T (1994) Organochlorine compounds in human milk, Porto Alegre, Brazil. Bull Environ Contam Toxicol 53:357-360

Bernard A, Broeckaert F, De Poorter G, De Cock A, Hermans C, Saegerman C et al (2002) The Belgian PCB/Dioxin incident: analysis of the food chain contamination and health risk evaluation. Environ Res A 88:1-18

Bernes C (1998) Persistent organic pollutants. Monitor 16, Swedish EPA. Stockholm, Sweden

Bingham AG, Edmunds CJ, Graham BW, Jones MT (1989) Determination of PCDDs and PCDFs in car exhaust. Chemosphere 19:669-673

Blüthgen A, Heeschen W, Ruoff U (1996) Die belastung von tankwagensammelmilch mit 2, 3, 4, 7, 8-Pentachlorodibenzofuran in Schleswig-Holstein. Milchwissenschaft 50 (6)

Bolt A, de Jong APJM (1993) Ambient air dioxin measurement in The Netherlands. Chemosphere 27:73-81

Brenez C, Gerkens P, Mazzucchelli G, Jauniaux T, Eppe G, De Pauw E, De Pauw-Gilet MC (2004) A strategy to identify specific biomarkers related to the effects of a PCDD/F mixture on the immune system of marine mammals. Talanta 63:12251230

Brouwer A, Ahlborg UG, Van den Berg M, Birnbaum LS, Boersma ER, Bosveld B et al (1995) Functional aspects of development toxicity of polyhalogenated aromatic hydrocarbons in experimental animals and human infants. Eur J Pharmacol Environ Toxicol Pharmacol Sect 293:1-40

Buhler U, Greiner R (1996) Dioxin Emission der Diesel-fahzeuge und des Ubrigen Strassenverkehrs. Institutfur Verbrennungsmotoren und Kraftfahrwesen, Universitat Struttgart, Germany

Centers for Disease Control (CDC) (1998) Toxicological profile for chlorinated dibenzo- $p$-dioxins. US Department of Health and Human Services, Agency for Toxic Substances and Disease Registry, Atlanta, GA

Chang MB, Lin JJ (2001) Memory effect on the dioxin emissions from municipal waste incineration in Taiwan. Chemosphere 45:1151-1157

Chang MB, Chang SH, Chen YW, Hsu HCh (2004) Dioxin emission factors for automobiles from tunnel air sampling in Northern Taiwan. Sci Total Environ 325:129-138

California Air Resources Board (CARB) (1987) Determination of PCDD and PCDF emissions from motor vehicles. Test Report C86-029

Chen ChM (2004) The emission inventory of PCDD/PCDF in Taiwan. Chemosphere 54:1423-1420

Chen HL, Su HJ, Liao PC, Chen HC, Lee CC (2004) Serum PCDD/F concentration distribution in residents living in the vicinity of an incinerator and its association with predicted ambient dioxin exposure. Chemosphere 54:1421-1429

Cleverly DH, Winters D, Ferrario J, Schaum J, Schweer G, Buchert J et al (2000) The National Dioxin Air Monitoring Network (NDAMN): results of the first year of atmospheric measurements of CDDs, CDFs and dioxin-like PCBs in rural and agricultural areas of the United States: June 1998-June 1999. Organohalog Compd 45:248-251

Cleverly, D.H., Winters, D., Ferrario, J., Schaum, J., Riggs, K., Hartford P., et al. (2001) The national dioxin air monitoring network (NDAMN): measurements of CDDs, CDFs and coplanar PCBs at 15 rural and 6 national park areas of the United States. Organohalog Compd 51:1-4

Conseil Supérieur d'Hygiéne Publique de France (1997) (Section de l'Alimentation et de la Nutrition), Recommandations sur la dioxine, Avis du 17/03/1997

Coutinho M, Pereira M, Rodrigues R, Borrego C (2006) Impact of medical waste incineration in the atmospheric PCDD/F levels of Porto, Portugal. Sci Total Environ 362:157-165
Czuczwa JM, McVeety BD et al (1984) Polychlorinated dibenzo- $p$ dioxins and dibenzofurans in sediments from Siskiwit Lake, Isle Royale. Science 226:568-569

Dahlgren J, Warshaw R, Horsak RD, Parker FM III, Takhar H (2003) Exposure assessment of residents living near a wood treatment plant. Environ Res 92:99-109

Davy CW (2004) Legislation with respect to dioxins in the workplace. Environ Int 30:219-233

De Fré R, Wevers M (1998) Measurements of dioxins in deposition and in cow's milk in Belgium. Organohalog Compd 38:113116

Defour S, Fraisse D, Scherr MC, Schenpp B, Le Querrec F (1997) Analysis of polychlorodibenzo-dioxins (PCDDs) and polychlorodibenzofurans (PCDFs) in dairy products in France. Organohalog Compd 32:283-285

Denison MS, Heath-Pagliuso S (1998) The Ah receptor: a regulator of the biochemical and toxicological actions of structurally diverse chemicals. Bull Environ Contam Toxicol 61:557-568

Deml E, Mangelsdorf I, Greim H (1996) Chlorinated dibenzodioxins and dibenzofurans (PCDD/F) in blood and human milk of non-occupationally exposed persons living in the vicinity of a municipal waste incinerator. Chemosphere 33:1941-1950

De Vito MJ, Birnbaum LS (1995) Dioxins: model chemicals for assessing receptor-mediated toxicity. Toxicol 102:115-123

Diaz-Ferrero J, Rodriguez-Larena MC, Cornellas L, Jlménez B (1997) Bioanalytical methods applied to endocrine disrupting polychlorinated biphenyls, polychlorinated dibenzo- $p$-dioxins and polychlorinated dibenzofurans. A review. Trends Anal Chem 16:563-573

Duarte-Davidson R, Sewart A, Alcock RE, Cousins IT, Jones KC (1997) Exploring the balance between sources, deposition, and the environmental burden of PCDD/Fs in the U.K. terrestrial environment: an aid to identifying uncertainties and research needs. Environ Sci Technol 31:1-11

Durand B, Dufour B, Vindel E, Fraisse D (2000) A survey of PCDD and PCDF in French long-life half-skimmed drinking milk. Chemosphere 41:865-869

Dyke P, Coleman P, James R (1997) Dioxins in ambient air, bonfire night 1994. Chemosphere 34:1191-1201

Eadon G, Kaminsky L et al (1986) Calculation of 2,3,7,8-TCDD equivalent concentrations of complex environmental contaminant mixtures. Environ Health Perspect 70:221-227

EC No.194/97 (1999) Setting maximum levels for certain contaminants in foodstuffs amending commission regulation (EC) No.194/97 of 31 January 1997. Brussels, January 2000 DG ENTR/E/1GS D(99)

Environmental Protection Agency (EPA) (2004) Exposure and human health reassessment of 2,3,7,8-tetrachlorodibenzo- $p$-dioxin (TCDD) and related compounds: National Academy of Sciences (NAS) review draft

European Commission Health and Consumer Protection DirectorateGeneral, 2000. Assessment of dietary intake of dioxins and related PCBs by the population of EU Member States. European Union, Brussels

European Commission (2001) Scientific Committee on Food. Opinion of the Scientific Committee on Food on the risk assessment of dioxins and dioxin-like PCBs in food. Update based on new scientific information available since the adoption of the SCF opinion of 22nd November 2000. CS/CNTM/DIOXIN/20 final. Adopted on 30 May 2001

Falk C, Hanrahan L, Anderson HA, Kanarek MS, Draheim L, Needham L, Patterson D Jr (1999) Body burden levels of dioxin, furans, and PCBs among frequent consumers of Great Lakes sport fish. Environ Res 80:19-25 
Fernandes A, White S, D'Silva K, Rose M (2004) Simultaneous determination of PCDDs, PCDFs, PCBs and PBDEs in food. Talanta 63:1147-1155

Fernandez-Salguero PM, Hilbert DM, Rudikoff S, Ward JM, Gonzalez FJ (1996) Aryl-hydrocarbon receptor-deficient mice are resistant to 2,3,7,8- tetrachlorodibenzo- $p$-dioxin-induced toxicity. Toxicol Appl Pharmacol 140:173-179

Ferrario J, Byrne C (2000) The concentration and distribution of 2,3,7,8-dibenzo- $p$-dioxins/-furans in chickens. Chemosphere 40:221-224

Fiedler H (1996) Sources of PCDD/PCDF and impact on the environment. Chemosphere 32:55-64

Fiedler H, Lau C, Cooper K, Andersson R, Hjelt M, Rappe C et al (1997a) PCDD/PCDF in the atmosphere of southern Mississippi, USA. Organohalog Compd 33:122-127

Fiedler H, Cooper K, Bergck S, Hjelt M, Rappe C (1997b) Polychlorinated dibenzo- $p$-dioxins and polychlorinated dibenzofurans (PCDD/PCDF) in food samples collected in southern Mississippi, USA. Chemosphere 34:1411-1419

Fiedler H, Rottler H, Peichl L, KnetschG, Basler A (2000) Concentrations ofPCDD/PCDF in atmospheric samples inGermany. Organohalog Compd 45:264-268

Fletcher CL, McKay WA (1993) Polychlorinated dibenzo- $p$-dioxins (PCDDs) and dibenzofurans (PCDFs) in the aquatic environment-a literature review. Chemosphere 26:1041-1069

Flesch-Janys D, Becher H, Gurn P, Jung D, Konietzko J, Manz A, Papke O (1996) Elimination of polychlorinated dibenzo- $p$ dioxins and dibenzofurans in occupationally exposed persons. $\mathbf{J}$ Toxicol Environ Health 47:363-378

Focant JF, Eppe G, Pirard C, Massart AC, André JE, De Pauw E (2002) Levels and congener distributions of PCDDs, PCDFs and non-ortho PCBs in Belgian foodstuffs Assessment of dietary intake. Chemosphere 48:167-179

Food Standards Agency (FSA) (2003) Dioxins and dioxin-like PCBs in the UK diet: 2001 total diet study samples. Report 38/03

Freeman NCG, de Tejada SS (2002) Methods for collecting time/ activity pattern information related to exposure to combustion products. Chemosphere 49:979-992

Freijer JI, Hoogerbrugge R, van Klaveren JD, Traag WA, Hoogenboom LAP, Liem AKD (2001) Dioxins and dioxin-like PCBs in foodstuffs: Occurrence and dietary intake in The Netherlands at the end of the 20th century. RIVM report 639102022, Bilthoven, The Netherlands

Fries GF (1995) A review of the significance of animal food products as potential pathways of human exposures to dioxins. J Anim Sci 73:1639-1650

Fries GF, Feil VJ, Zaylskie RG, Bialek KM, Rice CP (2002) Treated wood in livestock facilities: relationships among residues of pentachlorophenol, dioxins, and furans in wood and beef. Environ Pollut 116:301-307

Fuoco R, Colombini MP, Abete C (1994) Determination of polychlorobiphenyls in environmental samples from Antarctica. Int J Environ Anal Chem 55:15-25

Fueno H, Tanaka K, Sugawa S (2002) Theoretical study of the dechlorination reaction pathways of octachlorodibenzo- $p$-dioxin. Chemosphere 48:771-778

Fürst P, Krüger Chr, Meemken HA, Groebel W (1989) PCDD and PCDF levels in human milk-dependence on the period of lactation. Chemosphere 18:439-444

Fürst P, Fürst C, Groebel W (1990) Levels of PCDDs and PCDFs in food-stuffs from the Federal Republic of Germany. Chemosphere 20:787-792

Fürst P, Fürst C, Wilmers K (1991) Body burden with PCDD and PCDF from food. In: Gallo MA, Scheuplein RJ, Van Der Heijden KA (eds) Biological basis for risk assessment of dioxins and related compounds, Banbury Report 35. Cold Spring Harbor Laboratory Press, NY, pp 133-142

Fürst P, Fürst C, Wilmers K (1992) PCDDs and PCDFs in human milk-statistical evaluation of a 6-years survey. Chemosphere 25:1029-1038

Gertler AW, Sagebiel JC, Dippel WA, Farina RJ (1998) Measurements of dioxin and furan emission factors from heavy-duty diesel vehicles. J Air Waste Manage Assoc 48:276-278

Glynn AW, Atuma S, Aune M, Darnerud PO, Cnattingius S (2001) Polychlorinated biphenyl congeners as markers of toxic equivalents of polychlorinated biphenyls, dibenzo- $p$-dioxins and dibenzofurans in breast milk. Environ Res 86:217-228

Goldfarb TD, Harrad SJ (1991) Consideration of the environmental impact of the volatilization of PCDDs and PCDFs. Chemosphere 23:1669-1674

González MJ, Jiménez B, Hernández LM, Gonnord MF (1996) Levels of PCDDs and PCDFs in human milk from populations in Madrid and Paris. Bull Environ Contam Toxicol 56:197-204

Götz R, Enge P, Friesel P, Roch K, Kjeller LO, Klup SE, Rappe C (1994) Sampling and analysis of water and suspended particulate matter of the river Elber for polychlorinated dibenzo- $p$-dioxins (PCDDs) and dibenzofurans(PCDFs). Chemosphere 28:63-74

Gribble GW (1994) The natural production of chlorinated compounds. Environ Sci Technol 28:310-319

Grochowalski A, Lassen C, Holtzer M, Sadowski M, Hudyma T (2006) Determination of PCDDs, PCDFs, PCBs and HCB emissions from the metallurgical sector in Poland. Environ Sci Pollut Res 10:49-56

Grossi G, Lichtig J, Krauss P (1998) PCDD/F, PCB and PAH content of Brazilian compost. Chemosphere 37:2153-2160

Guruge KS, Tanabe S (2004) Polychlorinated dibenzo- $p$ dioxins, dibenzofurans and dioxin-like biphenyls in biota from Sri Lankan coast. Mar Pollut Bull 48:1004-1008

Guruge KS, Seike N, Yamanaka N, Miyazaki S (2005) Polychlorinated dibenzo- $p$-dioxins, -dibenzofurans, and biphenyls in domestic animal food stuff and their fat. Chemosphere 58:883889

Hagenmaier H, Dawidowsky N, Weberru BU, Hutzinger O, Schwind KH, Thomas H (1990) Emission of polychlorinated dibenzodioxins and dibenzofurans from combustion engines. Organohalog Compd 2:329-334

Hagenmaier H, Krauss P, Vatter J, Walczok M (1995) Contributions of diesel-powered vehicles and wood burning to overall PCDD/F emissions. Organohalog Compd 22:49-54

Hallikainen A, Vartiainen T (1998) Food control surveys of polychlorinated dibenzo- $p$-dioxins and dibenzofurans and intake estimates. Food Addit Contam 14:355-366

Hanrahan LP, Falk C, Anderson HA, Draheim L, Kanarck MS, Olson J (1999) Serum PCB and DDE levels of frequent Great Lakes sport fish consumers-a first look. Environ Res 80:26-37

Hashimoto S, Wakimoto T, Tatsukawa R (1990) PCDDs in the sediments accumulated about 8120 years ago from Japanese coastal areas. Chemosphere 21:825-835

Hayward DG, Nortrup D, Gardner A, Clower M Jr (1999) Elevated TCDD in chicken eggs and farm-raised catfish fed a diet with ball clay from a southern United States mine. Environ Res A $81: 248-256$

Hays SM, Aylward LL (2003) Dioxins risks in perspective: past, presence, and future Regulat. Toxicol Pharmacol 37:202-217

Hendriks AJ, Wever H, Olie K et al (1996) Monitoring and estimating concentrations of polychlorinated biphenyls, dioxins, and furans in cattle milk and soils of Rhine-Delta foodplains. Arch Environ Contam Toxicol 31:263-270

Hippelein M, Kaupp H, Dorr G, Hutzinger O (1996) Baseline contamination assessment for a new resource recovery facility in 
Germany: Part II. Atmospheric concentrations of PCDD/F. Chemosphere 32:1605-1616

Hoeksta EJ, de Weerd H, de Leer EWB, Brinkman UATh (2000) Natural formation of chlorinated phenols, dibenzo- $p$-dioxins and dibenzofurans in soil of a Douglas fir forest. Organohalog Compd 46:5-8

Hoogenboom R, Bovee T, Portier L, Bor G, van der Berg G, Onstenk C, Traag W (2004) The German bakery waste incident; use of a combined approach of screening and confirmation for dioxins in feed and food. Talanta 63:1249-1253

Hooper K, Petreas MX, She J et al (1997) Analysis of breast milk to assess exposure to chlorinated contaminants in Kazakhstan: PCBS and organochlorine pesticides in Southern Kazakhstan. Environ Health Perspect 105:1250-1254

Hooper K, Petreas MX, Chuvakova T, Kazbekova G, Druz N, Seminova G et al (1998) Analysis of breast milk to assess exposure to chlorinated contaminants in Kazakstan: high levels of 2,3,7,8-tetrachlorodibenzo- $p$-dioxin (TCDD) in agricultural villages of Southern Kazakstan. Environ Health Perspect 106:797806

Hooper K, Chuvakova T, Kazbekova G, Hayward D, Tulenova A, Petreas MX, Wade TJ, Benedict K, Cheng YY, Grassman J (1999) Analysis of breast milk to access exposure to chlorinated contaminants in Kazakhstan: sources of 2,3,7,8-tetrachlorodibenzo- $p$-dioxin (TCDD) exposures in an agricultural region of Southern Kazakhstan. Environ Health Perspect 107:447-457

Hori S, Konishi Y, Kuwabara K (1999) Decrease of PCDDs, PCDFs and Co-PCBs levels in human milk from OSAKA (1973-1996). Organohalog Compd 44:141-145

Hylander LD, Sollenberg H, Westas H (2003) A three-stage system to remove mercury and dioxins in flue gases. Sci Total Environ 304:137-144

JECFA (2002) Polychlorinated dibenzodioxins, polychlorinated dibenzofurans, and coplanar polychlorinated biphenyls. In: Canady R, Crump K, Feeley M, Freijer J, Kogevinas M, Malisch R, Verger P, Wilson J, Zeilmaker M (eds) Safety evaluation of certain food additives and contaminants. Report of the 57th meeting of the Joint FAO/WHO Expert Committee on Food Additives and Contaminants. WHO Food Additives Series, vol 48. World Health Organization, Geneva, pp 451-664

Iben C, Bohm J, Tausch H, Leibetseder J, Luf W (2003) Dioxin residues in the edible tissue of broiler chicken. J Anim Physiol Anim Nutr 87:142-148

Institute of Medicine (IOM) (2001) Veterans and agent orange: update 2002. National Academic Press, Washington, DC

Institute of Medicine (IOM) (2005) Veterans and agent orange: update 2004. National Academic Press, Washington, DC

Inventory of Dioxin and Furan Releases in Poland, Report (2002) COWIA/S, Denmark and dk-TEKNIK ENERGY AND ENVIRONMENT, Denmark in cooperation with a group of Polish experts coordinated by Krzysztof Olendrzyński from National Emission Centre at the Institute of Environmental Protection in Warsaw

Irigaray P, Rychen G, Feidt C, Laurent F, Mejean L (2005) Behaviour of dioxin in pig adipocytes In: Lichtfouse É, Schwarzbauer J, Robert D (eds) Environmental chemistry. Green chemistry and pollutants in ecosystems. Springer, Berlin, pp 353-359

Ishida T, Hori M, Ishii Y, Oguri K, Yamada H (2005) Effects of dioxins on stress-responsive systems and their relevance to toxicity. J Dermatol Sci Suppl 1:105-112

Isosaari P, Pajunen H, Vartiainen T (2002) PCDD/F and PCB history in dated sediments of a rural lake. Chemosphere 47:575-583

Jacobs MN, Covaci A, Schepens P (2002) Investigation of selected persistent organic pollutants in farmed Atlantic salmon (Salmo salar), salmon aquaculture feed, and fish oil components of the feed. Environ Sci Technol 36:2797-2805
Jensen AA (1991) Transfer of chemical contaminants into human milk. In: Jensen AA, Slorach SA (eds) Chemical contaminants in human milk. CRC Press, Boca Raton, pp 9-19

Jödicke B, Ende M, Helge H, Neubert D (1992) Fecal excretion of $\mathrm{PCDDs} / \mathrm{PCDF}$ in a 3-month-old breast-fed infant. Chemosphere 25:1061-1065

Kim JG, Kim KS, Joo CH, You JC (2000) Exposure of PCDD/ DFs via air and food in Koreans. Organohalog Compd 47:314-317

Kim Y, Yang SH, Lee SY, Kim M (2001) Levels of PCDDs and PCDFs in two kinds of fast food in Korea. Chemosphere 43:851855

Kim HK, Masaki H, Matsumura T, Kamei T, Magara Y (2002) Removal efficiency and homologue patterns of dioxins in drinking water treatment. Water Res 36:4861-4869

Kim M, Kim S, Lee M, Cho B, Park J, Son S, Kim O (2004) Comparison of seven indicator PCBs and three coplanar PCBs in beef, pork, and chicken fat. Chemosphere 54:1533-1538

Kiviranta H, Purkunen R, Vartiainen T (1998) Levels and trends of $\mathrm{PCDD} / \mathrm{Fs}$ and PCBs in human milk in Finland. Chemosphere 38:311-323

Kiviranta H, Hallikainen A, Ovaskainen ML, Kumpulainen J, Vartiainen T (2001) Dietary intakes of polychlorinated dibenzo- $p$-dioxins, dibenzofurans and polychlorinated biphenyls in Finland. Food Addit Contam 18:945-953

Kiviranta H, Ovaskainen ML, Vartiainen T (2004) Market basket study on dietary intake of PCDD/Fs, PCBs, and PBDEs in Finland. Environ Int 30:923-932

Kociba RJ, Keeler PA, Park CN, Gehrich PJ (1976) 2,3,7,8Tetrachlorodibenzo-p-dioxin (TCDD): results of a 13week oral toxicity study in rats. Toxicol Appl Pharmacol 35:553-74

Koester CJ, Hites RA (1992) Wet and dry deposition of chlorinated dioxins and furans. Environ Sci Technol 26:1357-1383

Koopman-Esseboom C, Morse DC, Weisglas-Kuperus N et al (1994) Effects of dioxins and polychlorinated biphenyls on thyroid hormone status of pregnant women and their infants. Pediatr Res 36:468-473

Lai KP, Li W, Xu Y, Wong MH, Wong ChKC (2004) Dioxin-like components in human breast milk collected from Hong Kong and Guangzhou. Environ Res 96:88-94

LaKind JS, Berlin CM, Naiman DQ (2001) Infant exposure to chemicals in breast milk in the United States: what we need to learn from a breast milk monitoring program. Environ Health Perspect 109:75-88

Lampi P, Tolonen K, Vartiainen T, Tuomisto J (1992) Chlorophenols in lake bottom sediments: a retrospective study of drinking water contamination. Chemosphere 24:1805-1824

Laurent C, Feidt C, Grova N, Mpasii D, Lichtfouse E, Laurent F, Rychen G (2002) Portal absorption of ${ }^{14} \mathrm{C}$ after ingestion of spiked milk with ${ }^{14} \mathrm{C}$-phenanthrene, ${ }^{14} \mathrm{C}$-benzo(a)pyrene or ${ }^{14} \mathrm{C}$ TCDD in growing pigs. Chemosphere 48:843-848

Lavric ED, Konnov AA, De Ruyck J (2004) Dioxin levels in wood combustion-a review. Biomass Bioenerg 26:115-145

Lind Y, Darnerud PO, Aune M, Becker W (2002) Exponering fõr organiska miljökontaminanter via livsmedel. Report from the Swedish NFA (in Swedish), report 26

Liem AKD (1999) Dioxins and dioxin-like PCBs in foodstuffs, Levels and trends. Organohalog Compd 44:1-4

Llerena JJ, Abad E, Caixach J, Rivera J (2001) A new episode of PCDDs/PCDFs feed contamination in Europe: the choline chloride. Organohalog Compd 51:283-286

Llobet JM, Domingo JL, Bocio A, Casas C, Teixidó A, Müller L (2003) Human exposure to dioxins through the diet in Catalonia, Spain: carcinogenic and non-carcinogenic risk. Chemosphere 50:1193-1200 
Lohmann R, Jones K (1998) Dioxins and furans in air and deposition: a review of levels, behaviour and processes. Sci Total Environ 219:53-81

Lustenhouwer JWA, Olie K, Hutzinger O (1980) Chlorodibenzo-pdioxins and chlorodibenzofurans are trace components of fly ash and flue gas of some municipal incinerators in the Netherlands. Chemosphere 9:501-522

Mackay D, Shiu W, Ma K (1992) Monocyclic hydrocarbons, chlorobenzenes and PCBs. In: Illustrated handbook of physicochemical properties and environmental fate for organic chemicals, vol 1. Lewis Publishing Company, Michigan

Maervoet J, Chu SG, De Vos S, Covaci A, Voorspoels S, De Schrijver $R$ et al (2004) Accumulation and tissue distribution of selected polychlorinated biphenyl congeners in chickens. Chemosphere 57:61-66

Malisch R (1998) Update of PCDD/PCDF-intake from food in Germany. Chemosphere 37:1687-1698

Malisch R, Le Querrec F, Schnepp B, Fraisse D (1999) GermanFrench joint project: $\mathrm{PCDD} / \mathrm{F}$ in food samples from upper Rhine river valley. Organohalog Compd 43:369-372

Malisch R (2000a) Increase of the PCDD/F-contamination of milk, butter and meat samples by use of contaminated citrus pulp. Chemosphere 40:1041-1053

Malisch R (2000b) PCDD/F in kaolinitic clays and its relevance for feedingstuff, food and cosmetics. Organohalog Compd 47:326328

Marklund S, Rappe C, Tysklind M (1987) Identification of polychlorinated dibenzofurans and dioxins in exhausts from cars on leaded gasoline. Chemosphere 16:29-36

Marklund S, Andersson R, Tysklind M, Rappe C, Egebaeck KE, Bjoerkman E, Grigoriadis V (1990) Emissions of PCDDs and PCDFs in gasoline and diesel fueled cars. Chemosphere 20:553561

McLachlan MS (1993) Digestive tract absorption of polychlorinated dibenzo-p-dioxins, dibenzofurans, and biphenyls in a nursing infant. Toxicol Appl Pharmacol 123:68-72

Masunaga S, Yao Y, Ogura I, Sakurai T, Nakanishi J (2003) Source and behavior analyses of dioxins based on congener-specific information and their application to Tokyo Bay basin. Chemosphere 53:315-324

Matsumura F, Brewster DW, Madhuker BV, Bombick DW (1984) Alteration of rat hepatic plasma membrane function by $2,3,7,8$ tetrachlorodibenzo- $p$-dioxin (TCDD). Arch Environ Contam Toxicol 13:509-515

Matsuura N, Harada S, Ohyama Y et al (2001a) Effects of dioxins and polychlorinated biphenyls (PCBs) on thyroid function in infants born in Japan-report from research on environmental health. Clin Pediatr Endocrinol 10:333-338

Matsuura N, Uchiyama T, Tada H, Nakamura Y, et al (2001b) Effects of dioxins and polychlorinated biphenyls (PCBs) on thyroid function in infants born in Japan-the second report from research on environmental health. Chemosphere 45:1167-1171

Mayer R (1995) Low levels of polychlorinated dibenzo- $p$-dioxins and dibenzofurans in cow's milk from South Germany. Organohalog Compd 26:109-111

McLachlan MS, Richter W (1998) Uptake and transfer of PCDD/F by cattle fed naturally contaminated feedstuffs and feed contaminated as a result of sewage sludge application Part 1: Lactating cows. J Agric Food Chem 46:1166-1172

Michalek JE, Tripathi RC, Caudill SP, Pirkle JL (1992) Investigation of TCDD half-life heterogeneity in veterans of Operation Ranch Hand. J Toxicol Environ Health 35:29-38

Mitrou PI, Dimitriadis G, Raptis SA (2001) Toxic effects of 2,3,7,8tetrachlorodibenzo- $p$-dioxin and related compounds. Eur J Int Med 12:406-411
Morrill LG, Mahilum BC, Mohiuddin SH (1982) Organic compounds in soils: sorption, degradation and persistence. Ann Arbor Science Publ, Ann Arbor, pp 35-54

Muir DCG, Omelchenko A, Grift NP, Savoie DA, Lockhart WL, Wilkinson P, Brunskill GJ, (1996) Spatial trends and historical deposition of polychlorinated biphenyls in Canadian midlatitude and arctic lake sediments. Environ Sci Technol 30:3609-3617

Nagayama J, Iida T, Hirakawa H et al (1997) Effects of lactational exposure to chlorinated dioxins and related chemicals on thyroid functions in Japanese babies. Organohalog Compd 33:446-450

Nakagawa R, Hirakawa H, Iida T, Matsueda T (1999) Maternal body burden of organochlorine pesticides and dioxins. J AOAC Int 82:716-724

North Atlantic Treaty Organization (NATO) (1988a) Committee on the challenges of modern society (Report No. 176). Brussels

North Atlantic Treaty Organization (NATO) (1988b) Committee on the challenges of modern society (Report No. 178). Brussels

Noren K (1988) Changes in the levels of organochlorine pesticides, polychlorinated biphenyls, dibenzo- $p$-dioxins and dibenzofurans in human milk from Stockholm, 1972-1985. Chemosphere 17:39-49

Oehme M, Larssen S, Brevik EM (1991) Emission factors of PCDD/ $\mathrm{CDF}$ for road vehicles obtained by a tunnel experiment. Chemosphere 23:1699-1708

Parzefall W (2002) Risk assessment of dioxin contamination in human food. Review. Food Chem Toxicol 40:1185-1189

Päpke O (1998) PCDD/PCDF: human background data for Germany, a 10-year experience. Environ Health Perspect 106:723-731

Päpke O, Ball M, Lis A (1992) Various PCDD/PCDF patterns in human blood resulting from different occupational exposures. Chemosphere 25:1101-1108

Paumgartten FJR, Cruz CM, Chahoud I, Palavinskas R, Mathar W (2000) PCDDs, PCDFs, PCBs, and other organochlorine compounds in human milk from Rio de Janeiro, Brazil. Environ Res 83:293-297

Persky V, Turyk M, Anderson HA, Hanrahan LP, Falk C, Steenport DN, Chatterton R Jr, Freels S (2001) The effects of PCB exposure and fish consumption on endogenous hormones. Environ Health Perspect 109:1275-1283

Pirard C, Pauw E (2005) Uptake of polychlorodibenzo-p-dioxins, polychlorodibenzofurans and coplanar polychlorobiphenyls in chickens. Environ Int 31:585-591

Pluim HJ, Wever J, Koppe JG, van der Slikke JW, Olie K (1993a) Intake and faecal excretion of chlorinated dioxins and dibenzofurans in breast-fed infants at different ages. Chemosphere 26:1947-1952

Pluim HJ, Kramer I, Van der Slikke JW, Koppe JG, Olie K (1993b) Levels of PCDDs and PCDFs in human milk: dependence on several parameters and dietary habits. Chemosphere 26:1889_ 1895

Pollitt F (1999) Polychlorinated dibenzodioxins and polychlorinated dibenzofurans. Regul Toxicol Pharmacol 30:63-68

Ramos L, Eljarrat E, Hernandez LM, Alonso L, Rivera J, Gonzalez MJ (1997) Levels of PCDDs and PCDFs in farm cow's milk located near potential contaminant sources in Asturias (Spain). Comparison with levels found in control, rural farms and commercial pasteurized cow's milks. Chemosphere 35:21672179

Rappe C, Anderson R (2000) Concentrations of PCDDs in ball clay and kaolin. Organohalog Compd 46:9-11

Ryan JJ, Lizotte R et al (1987) Human tissue levels of PCDDs and PCDFs from a fatal pentachlorophenol poisoning. Chemosphere 16:1989-1996

Ryan JJ, Lizotte R, Panopio LG, Shewchuk C, Lewis DA, Sun WF (1993) Polychlorinated dibenzo-p-dioxins (PCDDs) and polychlorinated dibenzo-furans (PCDFs) in human milk samples 
collected across Canada in 1986-87. Food Addit Contam $10: 419-428$

Ryan JV, Gullett BK (2000) On-road emission sampling of a heavy duty diesel vehicle for polychlorinated dibenzo-dioxins and polychlorinated dibenzofurans. Environ Sci Technol 34:44834489

Quaß U (ed) (1997) identification of relevant industrial sources of dioxins and furans in Europe. Final Report of the European Commission, DG-XI, No: 43, Landesumweltamt NordrheinWestfalen, Essen

Quaß U, Fermann MW, BrZoker G (2000) Steps towards a European dioxin emission inventory. Chemosphere 40:1125-1129

Sasamoto T, Horii Sh, Ibe A, Takada N, Shirota K (2006) Concentration changes of PCDDs, PCDFs, and dioxin-like PCBs in human breast milk samples as shown by a follow-up survey. Chemosphere 64:642-649

SCF (2001) European Commission, Scientific Committee on Food, Brussels, Belgium. Opinion on the risk assessment of dioxins and dioxin-like PCBs in food (22 November 2000). Opinion on the risk assessment of dioxins and dioxins-like PCBs in food (update based on the new scientific information available since the adoption of the SCF opinion of 22 November 2000, 30 May 2001)

Schecter A (1998) A selective historical review of congener-specific human tissue measurements as sensitive and specific biomarkers of exposure to dioxins and related compounds. Environ Health Perspect 106:737-742

Schecter A, Dekin A, Weerasinghe NCA, Arghestani S, Gross ML (1988) Sources of dioxins in the environment: a study of PCDDs and PCDFs in ancient, frozen Eskimo tissue. Chemosphere 17:627-631

Schecter A, Ryan JJ et al (1990) Decrease over a six year period of dioxin and dibenzofurans tissue levels in a single patient following exposure. Chemosphere 20:911-917

Schecter A, Jiang K, Päpke O, Fürst P, Fürst C (1994) Comparison of dibenzodioxin levels in blood and milk in agricultural workers and others following pentachlorophenol exposure in China. Chemosphere 29:2371-380

Scheter A, Cramer P, Bogess K, Stanley J, Olson J (1995) Levels of dioxins, dibenzofurans, DDE and PCB congeners in pooled food samples collected at supermarkets across the United States. Organohalog Compd 26:125-128

Schecter A, Ryan JJ, Päpke O (1998) Decrease in levels and body burden of dioxins, dibenzofurans, PCBS, DDE, and HCB in blood and milk in a mother nursing twins over a thirty-eight month period. Chemosphere 37:1807-1816

Schecter A, Miyata H et al (1999) Chloracne and elevated dioxin and dibenzofurans levels in the blood of two Japanese municipal incinerator workers and of the wife of one worker. Organohalog Compd 44:247-250

Schecter A, Cramer P, Boggess K, Stanley J, Päpke O, Olson J et al (2001a) Intake of dioxins and related compounds from food in the U.S. population. J Toxicol Environ Health 63:1-18

Schecter A, Dai LC et al (2001b) Recent dioxin contamination from Agent Orange in residents of a southern Vietnam city. J Occup Environ Med 43:435-443

Schecter A, Gasiewicz TA (eds) (2003) Dioxins and health, 2nd edn. Wiley, Hoboken

Schecter A, Birnbaum L, Ryan JJ, Constable JD (2006) Dioxins: an overview. Environ Res 101:419-428

Schlotke F, Sieber R (1998) Berechnung des Verbrauchs an Nahrungsenergie, Energieträgern, Nahrungsfasern, Vitaminen, Mineralstoffen und Spurenelementen. In: Keller U, Lüthy J, Amadó R et al (eds) Vierter Schweizerischer Ernährungsbericht. EDMZ, Berne, pp 18-27
Schmid R, Gujer E, Zennegg M, Studer Ch (2003) Temporal and local trends of PCDD/F levels in cow's milk in Switzerland. Chemosphere 53:129-136

Schmitz HJ, Hagenmaier A, Hagenmaier HP, Bock KW, Schrenk D (1995) Potency of mixtures of polychlorinated biphenyls as inducers of dioxin receptor-regulated CYP1A activity in rat hepatocytes and H4IIE cells. Toxicology 99:47-454

Schrenk D, Lipp HP, Wiesmuller T, Hagenmaier H, Bock KW (1991) Assessment of biological activities of mixtures of polychlorinated dibenzo- $p$-dioxins: comparison between defined mixtures and their constituents. Arch Toxicol 65:114-118

Schroijen C, Windal I, Goeyens L, Baeyens W (2004) Study of the interference problems of dioxin-like chemicals with the bioanalytical method CALUX. Talanta 63:1261-1268

Schuhmacher M, Domingo JL, Llobet JM, Kiviranta H, Vartiainen T (1999) PCDD/F concentrations in milk of nonoccupationally exposed women living in southern Catalonia, Spain. Chemosphere 38:995-1004

Schulte E, Malisch R (1984) Calculation of the real PCB content in environmental samples II: gas chromatographic determination of the PCB concentration in human milk and butter. Z Anal Chem 319:54-59

Schwirzer SMG, Hofmaier AM, Kettrup A, Nerdinger PE, Schramm KW, Thoma W, Wegenke M, Wiebel FJ (1998) Establishment of a simple cleanup procedure and bioassay for determining 2,3,7,8-tetrachlorodibenzo- $p$-dioxin toxicity equivalents of environmental samples. Ecotoxicol Environ Saf 41:77-82

SCOOP (2000) Scientific co-operation on questions relating to food "assessment of dietary intake of dioxins and related PCBs by the population of EU member states" Task 3.2.5-Final report7 June

Scortichini G, Diletti G, Torreti L, Forti AF, Scarpone R, Migliorati G (2001) Food and animal feeds contamination by PCDDs-PCDFs in Italy in years 1999 and 2000: incidence and TEQ congeners patterns. Organohalog Compd 51:400-403

Sin DW, Choi JY, Louie PK (2002) A study of polychlorinated dibenzo- $p$-dioxins and dibenzofurans in the atmosphere of Hong Kong. Chemosphere 47:647-653

Smirnov AD, Schecter A, Päpke O, Beljak AA (1996) Conclusion from UFA, Russia, drinking water dioxin clean up experiments involving different treatment technologies. Chemosphere 32:479-489

Stenhouse I, Moncur J, Kocan T, Violova A (1998) Dioxin levels in the ambient air in Slovaka. Organohalog Compd 39:77-80

Stevens JB, Swackhamer DL (1989) Environmental pollution: a multimedia approach to modeling human exposure. Environ Sci Technol 3:1180-1186

Srogi K (2007a) Determination of PCDDs/PCDFs in human environment. Chemik (in Polish)

Srogi K (2007b) Overview of analytical methodologies for dioxin analysis, Anal Lett (in press)

Svenson A, Kjeller LO, Rappe C (1989) Enzyme-mediated formation of 2,3,7,8-tetrasubstituted chlorinated dibenzodioxins and dibenzofurans. Environ Sci Technol 23:900-902

Svensson BG, Nilsson A, Hansson M, Rappe C, Ákesson B, Skerfving S (1991) Exposure to dioxins and dibenzofurans through the consumption of fish. N Engl J Med 324:8-12

Takekuma M, Saito K, Ogawa M, Matumoto R, Kobayashi S (2004) Levels of PCDDs, PCDFs and Co-PCBs in human milk in Saitama, Japan, and epidemiological research. Chemosphere 54:127-135

Theelen RM, Liem AKD, Slob W, Wijnen JH (1993) Intake of 2,3,7,8-chlorine substituted dioxins, furans and planar PCBs from food in The Netherlands: median distribution. Chemosphere 27:1625-1635 
Thoma H, Mucke W, Kauert G (1990) Comparison of the polychlorinated dibenzo- $p$-dioxin and dibenzofuran in human tissue and human liver. Chemosphere 20:433-442

Till M, Behnisch P, Hagenmaier H, Bock KW, Schrenk D (1997) Dioxin- like components in incinerator fly ash: a comparison between chemical analysis data and results from a cell culture bioassay. Environ Health Perspect 105:1326-1332

Tokuda H (1999) Approaches towards dioxins reduction in water environment. J Jpn Soc Water Environ 22:722-723

Toyoda M, Uchibe H, Yanagi T, KonoY, Hori T, Iida T (1999) Dietary daily intakeof PCDDs, PCDFs and coplanar PCBs by totaldiet study in Japan. J Food Hygienic Soc Jpn40:98-110

Travis CC, Hattermer-Frey HA (1991) Human exposure to dioxin. Sci Tot Environ 104:97-127

Tsutsumi T, Yanagi T, Nakamura M, Kono Y, Uchibe H, Iida T et al (2001) Update of daily intake of PCDDs, PCDFs, and dioxin-like PCBs from food in Japan. Chemosphere 45:1129-1137

Turyk M, Anderson HA, Hanrahan LP, Falk C, Steenport DN, Needham LL, Patterson DG Jr, Freels S, Persky V, The Great Lakes Consortium (2006) Relationship of serum levels of individual PCB, dioxin, and furan congeners and DDE with Great Lakes sport-caught fish consumption. Environ Res 100:173-183

ten Tusscher GW, Koppe JG (2004) Perinatal dioxin exposure and later effects-a review. Chemosphere 54:1329-1336

Uehara R, Peng G, Nakamura Y, Matsuura N, Kondo N, Tada H (2006) Human milk survey for dioxins in the general population in Japan. Chemosphere 62:1135-1141

UNEP (2003) Standardized toolkit for identification and quantification of dioxin and furan releases, Geneva

US EPA-1613 (1994) Tetra through octachlorinated dioxins and furans by isotopic dilution HRGC-HRMS. Washington, DC

US EPA (1984) Ambient water quality criteria for 2,3,7,8-TCDD, EPA440/5-84-007

US EPA (2001) National primary drinking water standards. EPA 816F-01-007

Van den Berg M, Birnbaum LS et al (1998) Toxic equivalency factors (TEFs) for PCBs, PCDDs, PCDFs for humans and wildlife. Environ Health Perspect 106:775-792

Van Leeuwen FX, Feeley M, Schrenk D, Larsen JC, Farland W, Younes M (2000a) Dioxins: WHO's tolerable daily intake (TDI) revised. Chemosphere 40:1095-1101

Van Leeuwen FXR, Younes MM (2000b) Assessment of the health risk of dioxins: re-evaluation of the tolerable daily intake (TDI). Food Addit Contam 17:223-240

Van Loco J, Van Leeuwen SPJ, Roos P, Carbonnelle S, de Boer J, Goeynes L, Beernaert H (2004) The international validation of bio- and chemical-analytical screening methods for dioxins and dioxin-like PCBs: the DIFFERENCE project rounds 1 and 2. Talanta 63:1169-1182

Vartiainen T, Hallkainen A (1994) Polychlorinated dibenzo-pdioxin and polychlorinated dibenzofuran levels in cow milk samples, eggs samples and meat in Finland. Fresenius $\mathrm{J}$ Anal Chem 348:150-153

Vartiainen T, Mannio J, Korhonen M, Kinnunen W, Strandman T (1997) Levels of PCDD, PCDF and PCB in dated lake sediments in subarctic Finland. Chemosphere 34:1341-1350

Vindel E, Duhen K, Durand B, Dufour B, Guyonnet JP, Fraisse D, Le Querrec F, (1999) Evaluation of the mean concentration of dioxins and furans in heat treated milk at the consumption level in France. Organohalog Compd 43:437-440
Vollmuth S, Zajc A, Niessner R (1994) Formation of polychlorinated dibenzo- $p$-dioxins and dibenzofurans during the photolysis of pentachlorophenol-containing water. Environ Sci Technol 28:1145-1149

Wagrowski DM, Hites RA (2000) Insights into the global distribution of polychlorinated dibenzo-p-dioxins and dibenzofurans. Environ Sci Technol 34:2952-2958

Wang SL, Lin CY, Guo YL, Lin LY, Chou WL, Chang LW (2004) Infant exposure to polychlorinated dibenzo- $p$-dioxins, dibenzofurans and biphenyls (PCDD/Fs, PCBs) - correlation between prenatal and postnatal exposure. Chemosphere 54:14591473

Wevers M, De Fré R, Rymen T (1992) Dioxins and dibenzofurans in tunnel air. Organohalog Compd 9:321-324

Wevers M, De Fré R, Van Cleuvenbergen R, Rymen T (1993) Concentrations of PCDDs and PCDFs in ambient air at selected locations in Flanders. In: Organohalogen compounds: Dioxin '93. Emission control, transport and fate, environmental levels and ecotoxicology, vol 12. University of Bayreuth, Bayreuth, Germany, pp 123-126

Winters D, Lorber M, Cleverly D, Schaum J, Harless R, Dupuy A et al (1994) A statistical survey of dioxin-like compounds in the United States beef supply. In: Organohalogen compounds: Dioxin '94. Environmental levels, sources and formation, metabolism of PCB and related compounds, polar environment, national overviews, vol 20. Kyoto University, Kyoto, Japan, pp 73-77

Wittsiepe J, Schrey P, Ewers U, Selenka F, Wilhelm M (2000) Decrease of PCD/F levels in human blood from Germany over the past ten years (1989-1998). Chemosphere 40:1103-1109

World Health Organization (WHO) (1989) Polychlorinated dibenzopara-dioxins and dibenzofurans. Geneva, World Health Organization, 409 pp. (Environment Health Criteria Series No. 88)

World Health Organization (WHO) (1991) Consulation on tolerable daily intake from Food of PCDDs and PCDFs, WHO Regional Office for Europe, EUR/ICP/PCS 030

World Health Organization (WHO) (1996) Levels of PCBs, PCDDs and PCDFs in human milk. Bilthoven, World Health Organization, European Centre for Environment and Health (Environmental Health in Europe No. 3)

World Health Organization (WHO) (1997) Monographs on the evaluation of carcinogenic risks to humans. International Agency for Research on Cancer, WHO, Geneva

World Health Organization (WHO) (1998) Assessment of the health risk of dioxins: reevaluation of the tolerable daily intake (TDI). WHO European Centre for Environment and Health, International Programme on Chemical Safety, Geneva

Wouwe VN, Windal I, Vanderperren H, Eppe G, Xhrouet C, Massart AC, Debacker N, Sasse A et al (2004) Validation of the CALUX bioassay for $\mathrm{PCDD} / \mathrm{F}$ analyses in human blood plasma and comparison with GC-HRMS. Talanta 63:1157-1167

Wu Y, Li J, Zhao Y, Chen Z, Li W, Chen J (2002) Dietary intake of polychlorinated dibenzo- $p$-dioxins (PCDDs) and dibenzofurans (PCDFs) in populations from China. Organohalog Compd 57:221-223

Yang J, Shin D, Park S, Chang Y, Kom D, Ikonomou MG (2002) PCDDs, PCDFs, and PCBs concentrations in breast milk from two areas in Korea: body burden of mothers and implications for feeding infants. Chemosphere 46:419-428 